\title{
‡USGS

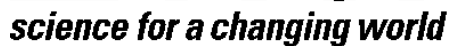

\section{Oceanographic Controls on Sedimentary and Geochemical Facies on the Peru Outer Shelf and Upper Slope}

By Michael A. Arthur and Walter E. Dean

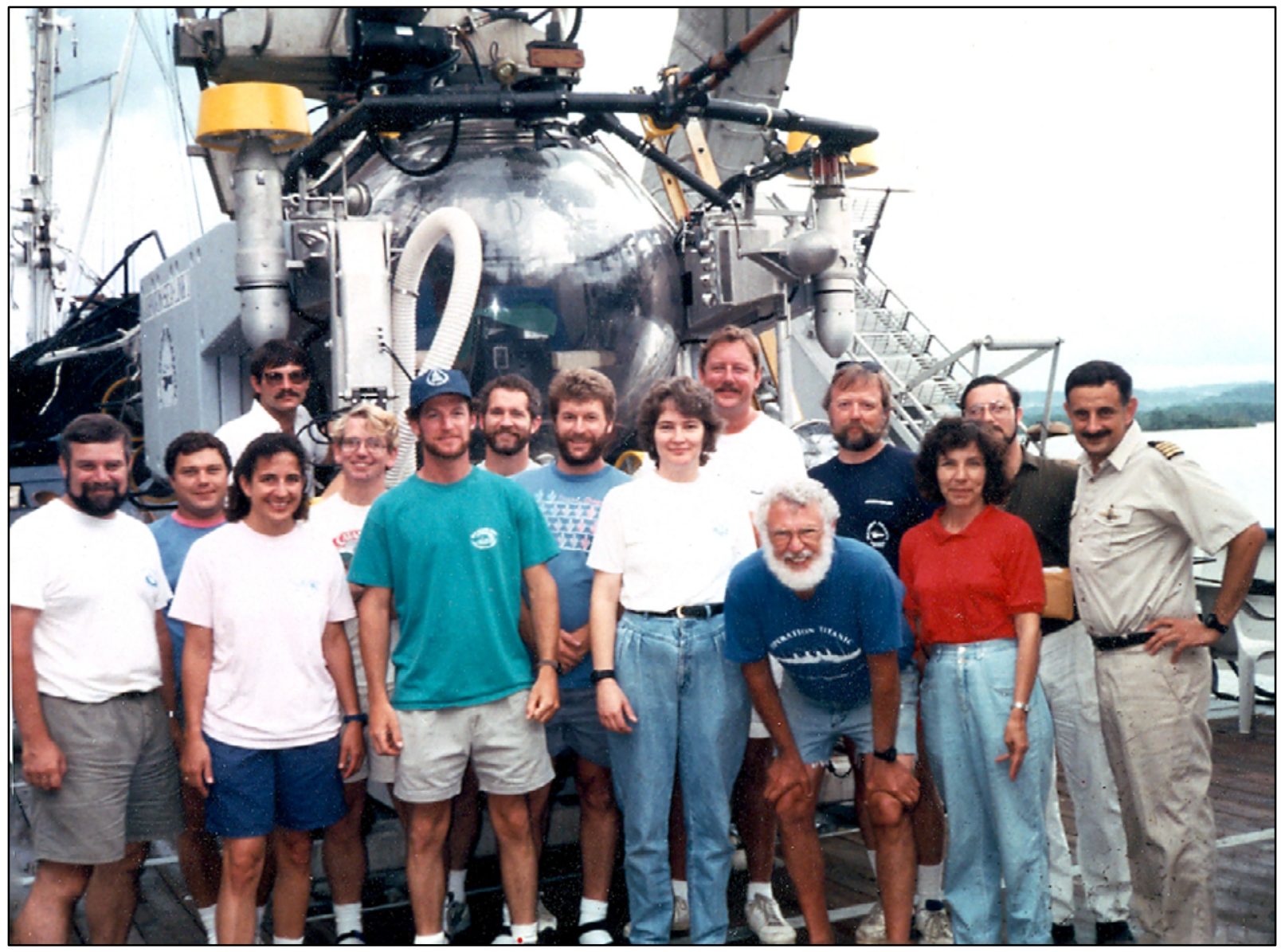

Open-File Report 2013-1105

U.S. Department of the Interior

U.S. Geological Survey 


\section{U.S. Department of the Interior \\ SALLY JEWELL, Secretary}

\section{U.S. Geological Survey \\ Suzette M. Kimball, Acting Director}

U.S. Geological Survey, Reston, Virginia: 2013

For more information on the USGS-the Federal source for science about the Earth, its natural and living resources, natural hazards, and the environment-visit http://www.usgs.gov or call 1-888-ASK-USGS

For an overview of USGS information products, including maps, imagery, and publications, visit $h$ ttp://www.usgs.gov/pubprod

To order this and other USGS information products, visit $h$ ttp://store.usgs.gov

Suggested citation:

Arthur, M.A., and Dean, W.E., 2013, Oceanographic controls on sedimentary and geochemical facies on the Peru outer shelf and upper slope: U.S. Geological Survey Open-File Report 2013-1105, 38 p., http://pubs.usgs.gov/of/2013/1105/

Any use of trade, product, or firm names is for descriptive purposes only and does not imply endorsement by the U.S. Government.

Although this report is in the public domain, permission must be secured from the individual copyright owners to reproduce any copyrighted material contained within this report.

Cover. Shipboard scientific party for Cruise SL10-92 of the Research Vessel Seward Johnson and the Deep Submersible Vessel Johnson Sea-Link II in October and November 1992. Daniel Schwartz, Captain of the $R / V$ Seward Johnson, is on the far right. 


\section{Contents}

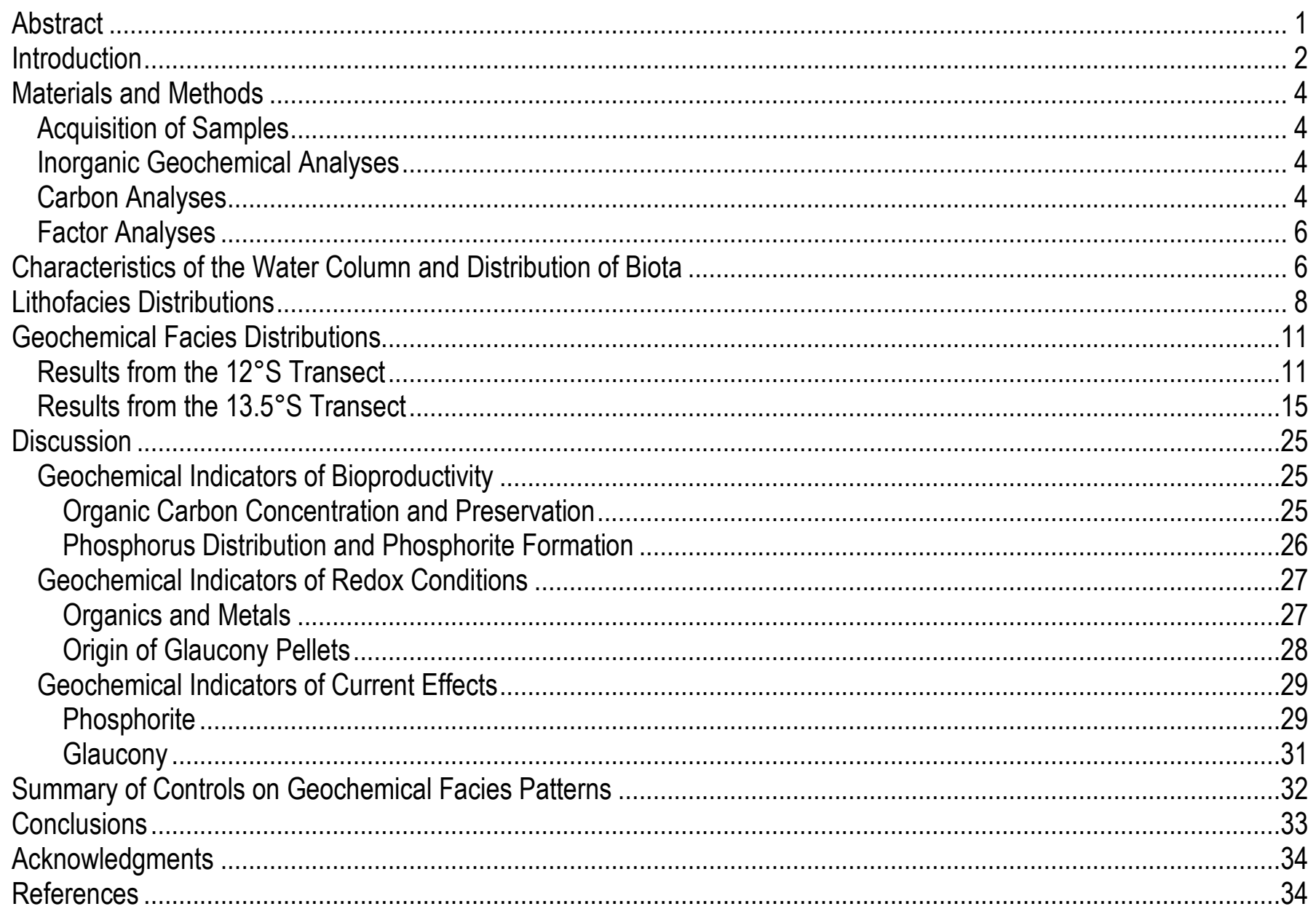

\section{Figures}

Figure 1. Map of the coast of Peru showing bathymetry; the average position of the oxygen minimum zone; the locations of selected salinity, temperature, and depth casts; and the locations of DS/V Johnson Sea-Link II submersible dive transects at $12^{\circ} \mathrm{S}$ and $13.5^{\circ} \mathrm{S}$ in October and November 1992.

Figure 2. Representative salinity, temperature, depth, and dissolved oxygen profiles taken at select locations on the $12^{\circ} \mathrm{S}$ and $13.5^{\circ} \mathrm{S}$ transects of the R/V Seward Johnson expedition on the Peru continental margin..

Figure 3. Map of bathymetry and bottom-current measurements made along two dive transects on the Peru margin

Figure 4. Examples of the progressive formation of phosphorite crusts and pavements on the Peru margin ...

Figure 5. Cross sections showing the lithology and characteristics of surface sediments as a function of water depth along two transects on the Peru margin ..... 
Figure 6. Plots of concentration of percent organic carbon, Rock-Eval pyrolysis Hydrogen Index in milligrams hydrocarbon per grams organic carbon, and percent calculated $\mathrm{CaCO}_{3}$-calcite in surface sediments versus water depth along two transects on the Peru margin

Figure 7. Plots of factor loadings versus water depth along the $12^{\circ} \mathrm{S}$ transect for factor 1 , organic carbon and metals, factor 2, phosphorite, and factor 3, clastic, from Q-mode factor analysis of chemical composition of surface sediments

Figure 8. Plots of factor loadings versus water depth along the $13.5^{\circ} \mathrm{S}$ transect for factor 1 , organic carbon and metals, factor 2, glaucony, factor 3, phosphorite, and factor 4, clastic, from Q-mode factor analysis of chemical composition of surface sediments

Figure 9. Plots of percent aluminum versus percent iron and percent potassium for all samples along the $13.5^{\circ} \mathrm{S}$ transect

Figure 10. Plots of percent total calcium versus percent total phosphorus for all samples along the $12^{\circ} \mathrm{S}$ transect and the $13.5^{\circ} \mathrm{S}$ transect.

Figure 11. Plot of percent aluminum versus percent total silicon and calculated percent excess $\mathrm{Si}$ versus water depth for the $13.5^{\circ} \mathrm{S}$ transect

Figure 12. Hypothetical sequence of phosphorite crust formation on the Peru margin

\section{Tables}

Table 1. Correlation coefficients between loadings for factors 1-4 and concentrations of major elements and trace elements in surface sediments on the $12^{\circ} \mathrm{S}$ transect

Table 2. Correlation coefficients between loadings for factors 1-4 and concentrations of major elements and trace elements in surface sediments on the $13.5^{\circ} \mathrm{S}$ transect.

Table 3. Composition of Q-mode factor analysis end-member samples and samples of glaucony pellets, phosphorite crusts and nodules, and dolomitic crusts collected along the $13.5^{\circ} \mathrm{S}$ transect on the Peru margin.

Table 4. Detrital and excess concentrations of selected trace elements in surface sediments

\section{Abbreviations Used in This Report}

$\begin{array}{ll}\mathrm{Al} & \text { aluminum } \\ \mathrm{As} & \text { arsenic } \\ \mathrm{Ba} & \text { barium } \\ \mathrm{Ca} & \text { calcium } \\ \mathrm{CaCO} & \text { calcium carbonate } \\ \mathrm{Cd} & \text { cadmium } \\ \mathrm{Ce} & \text { cerium } \\ \mathrm{CFA} & \text { carbonate-fluorapatite (phosphorite) } \\ \mathrm{cm} & \text { centimeter } \\ \mathrm{Co} & \text { cobalt } \\ \mathrm{Cr} & \text { chromium } \\ \mathrm{STD} & \text { salinity, temperature, and depth } \\ \mathrm{Cu} & \text { copper } \\ \mathrm{DO} & \text { dissolved oxygen } \\ \mathrm{Fe} & \text { iron } \\ \mathrm{g} & \text { gram } \\ \mathrm{Ga} & \text { gallium }\end{array}$




\begin{tabular}{|c|c|}
\hline HAP & hydroxyapatite \\
\hline $\mathrm{HC}$ & hydrocarbon \\
\hline HI & Hydrogen Index (Rock-Eval) \\
\hline $\mathrm{IC}$ & inorganic carbon \\
\hline ICP-AES & inductively coupled, argon-plasma, atomic emission spectrometry \\
\hline $\mathrm{K}$ & potassium \\
\hline $\mathrm{kHz}$ & kilohertz \\
\hline $\mathrm{La}$ & lanthanum \\
\hline $\mathrm{Li}$ & lithium \\
\hline $\mathrm{m}$ & meter \\
\hline $\mathrm{Mg}$ & magneseium \\
\hline $\mathrm{mg}$ & milligram \\
\hline $\mathrm{mm}$ & millimeter \\
\hline $\mathrm{Mn}$ & manganese \\
\hline Mo & molybdenum \\
\hline $\mathrm{Na}$ & sodium \\
\hline $\mathrm{Nb}$ & niobium \\
\hline $\mathrm{Nd}$ & neodymium \\
\hline $\mathrm{Ni}$ & nickel \\
\hline $\mathrm{OC}$ & organic carbon \\
\hline ODP & Ocean Drilling Program \\
\hline $\mathrm{OMZ}$ & oxygen-minimum zone \\
\hline $\mathrm{P}$ & phosphorus \\
\hline $\mathrm{Pb}$ & lead \\
\hline S & second \\
\hline $\mathrm{Sc}$ & scandium \\
\hline $\mathrm{Si}$ & silicon \\
\hline $\mathrm{Sr}$ & strontium \\
\hline $\mathrm{TC}$ & total carbon \\
\hline Th & thorium \\
\hline $\mathrm{Ti}$ & titanium \\
\hline $\mathrm{V}$ & vanadium \\
\hline VPDB & Vienna Pee Dee Belemnite marine carbonate standard \\
\hline $\mathrm{XRF}$ & X-ray fluorescence spectrometry \\
\hline $\mathrm{Y}$ & yttrium \\
\hline $\mathrm{Zn}$ & zinc \\
\hline$\mu \mathrm{m}$ & micrometer \\
\hline$\mu \mathrm{M}$ & micromoles per kilogram \\
\hline
\end{tabular}




\title{
Oceanographic Controls on Sedimentary and Geochemical Facies on the Peru Outer Shelf and Upper Slope
}

Michael A. Arthur ${ }^{1}$ and Walter E. Dean²

\begin{abstract}
Concentrations and characteristics of organic matter in surface sediments deposited under an intense oxygen-minimum zone (OMZ) on the Peru margin were mapped and studied in samples from deck-deployed box cores and push cores acquired by submersible on two east-west transects spanning depths of 75 to 1,000 meters $(\mathrm{m})$ at $12^{\circ} \mathrm{S}$ and $13.5^{\circ} \mathrm{S}$. On the basis of sampling and analyses of the top 1-2 centimeters $(\mathrm{cm})$ of available cores, three main belts of sediments were identified on each transect with increasing depth: (1) muds rich in organic carbon (OC); (2) authigenic phosphatic mineral crusts and pavements; and (3) glaucony facies.

Sediments rich in $\mathrm{OC}$ on the $12^{\circ} \mathrm{S}$ transect were mainly located on the outer shelf and upper slope (150-350 m), but they occurred in much shallower water (approximately $100 \mathrm{~m}$ ) on the $13.5^{\circ} \mathrm{S}$ transect. The organic matter is almost entirely marine as confirmed by Rock-Eval pyrolysis and isotopic composition of OC. Concentrations of OC are highest (up to 18 percent) in sediments within the OMZ where dissolved oxygen (DO) concentrations are $<5$ micromoles per kilogram $(\mu \mathrm{M})$. Even at these low concentrations of DO, however, the surface sediments from within the OMZ are dominantly unlaminated. Concentrations of DO may have the dominant effect on organic matter characteristics, but reworking of fine-grained sediment and organic matter by strong bottom currents with velocities as high as 30 centimeters per second $(\mathrm{cm} / \mathrm{s})$ on the slope between 150 and $300 \mathrm{~m}$ and redeposition on the seafloor in areas of lower energy and higher DO concentration also exert important controls on OC concentration and degree of oxidation in this region.

Phosphate-rich sediments and crusts occurred at depths of about 300 to $550 \mathrm{~m}$ on both transects. Nodular crusts of sediment cemented by carbonate-fluorapatite (CFA; phosphorite) or dolomite form within the OMZ. These phosphorite crusts evolve through cementation from light olive-green, stiff but friable, phosphatized claystone "protocrusts" through dense, dark phosphorite crusts, cemented breccias, and pavements. The degree of phosphatization and thickness of the crusts depend on the rates of sediment supply and on the strength and frequency of currents that re-expose crusts on the seafloor. Phosphorite crusts and pavements on the Peru margin can only become buried and incorporated into the geologic record once bottom currents slacken sufficiently to allow fine-grained sediment to accumulate.

Glaucony-rich surface sediments, relatively undiluted by other components, were found mainly in deeper water on the $13.5^{\circ} \mathrm{S}$ transect $(750 \mathrm{~m}$ to at least $1,067 \mathrm{~m})$. These sediments
\end{abstract}

\footnotetext{
${ }^{1}$ Pennsylvania State University-Department of Geosciences

${ }^{2}$ U.S. Geological Survey
} 
consist almost entirely of sand-size glaucony pellets. These widespread glaucony sands formed in place and were then concentrated and reworked by strong currents that winnowed away the fine-grained matrix. Although the glaucony occurs in sand-size pellets, the pellets are made up of aggregates of authigenic, platy, micaceous clay minerals. Glaucony is predominantly a potassium $(\mathrm{K})$, sodium $(\mathrm{Na})$, iron $(\mathrm{Fe})$, magnesium $(\mathrm{Mg})$ aluminosilicate with an approximate formula of $(\mathrm{K}, \mathrm{Na})\left(\mathrm{Fe}^{3+}, \mathrm{Al}, \mathrm{Mg}\right)_{2}(\mathrm{Si}, \mathrm{Al})_{4} \mathrm{O}_{10}(\mathrm{OH})_{2}$. The glaucony on the $13.5^{\circ} \mathrm{S}$ transect forms by alteration of one or more original "framework" minerals (carbonate and [or] aluminosilicates) to form pellital aggregates of $\mathrm{Fe}-, \mathrm{K}$-, and $\mathrm{Mg}$-rich clay minerals. Because $\mathrm{Fe}, \mathrm{K}$, and $\mathrm{Mg}$ are derived from seawater, sedimentation rates must be extremely slow in order for the original framework minerals to remain in contact with seawater. The close association of glaucony and phosphorite indicates a delicate balance between the slightly oxidizing conditions at the base of the OMZ that form glaucony and the slightly reducing conditions that mobilize iron and phosphate to form phosphorite.

\section{Introduction}

Systematic studies of sedimentary and geochemical facies distributions on upwelling margins involving mapping and sampling of facies types using submersible and sediment coring are needed to understand the effects of climate and sea level change on facies patterns and geochemical fluxes and to construct models for interpreting sedimentary sequences in ancient basins characterized by wind-driven upwelling and strong oxygen-minimum zones (OMZ) that impinge on basin slopes. The Peru margin, in particular, is a target for such investigations because it is characterized by upwelling of nutrient-rich Pacific intermediate waters that drives high biologic productivity, high fluxes of organic carbon (OC) to the seafloor, and the development of an intense midwater (100-700 meters [m]) OMZ. This region is climatically sensitive as evidenced by its sensitivity to El Niño-Southern Oscillation events and the Pacific Decadal Oscillation (Dettinger and others, 1998; Brown, 2011). Previous expeditions to the Peru margin have documented the processes involved in the formation of carbonate-fluorapatite (CFA; phosphorite) and dolomite crusts (Burnett, 1977; Froelich and others, 1988; Kulm and others, 1988; Garrison and Kastner, 1990; Burnett and others, 2000). Sediments in this region are characterized by relatively low fluxes of detrital clastic (aluminosilicate) material. They are dominated instead by authigenic and biogenic components related directly or indirectly to the accumulation of high concentrations of organic matter in response to coastal upwelling and relatively low concentrations of dissolved oxygen within an intense OMZ.

The investigation of the formation of authigenic minerals, particularly phosphorite crusts, was the objective of the $R / V$ Seward Johnson expedition with the submersible $D S / V$ Johnson Sea-Link II in October and November 1992. Our expedition took place during the protracted 1991-1992 El Niño conditions, so it is difficult to assert that the distribution of dissolved oxygen (DO), temperature, fauna, and surface-sediment characteristics that we observed are normal for the margin. A variety of deck-operated coring devices; profiles of salinity, temperature, depth, and dissolved oxygen (STD-DO); benthic flux chambers; pump-filter stations; and submersible deployments were used for direct and remote sampling and observation of the seafloor and water column along two east-west transects across the Peru margin at about $13.5^{\circ} \mathrm{S}$ and $12^{\circ} \mathrm{S}$ and at a depth range of 75 to $1,000 \mathrm{~m}$ (fig. 1). Here we report results of these surveys and initial sedimentological and geochemical studies of the sediments at the surface $(1-2$ centimeters $[\mathrm{cm}])$. 


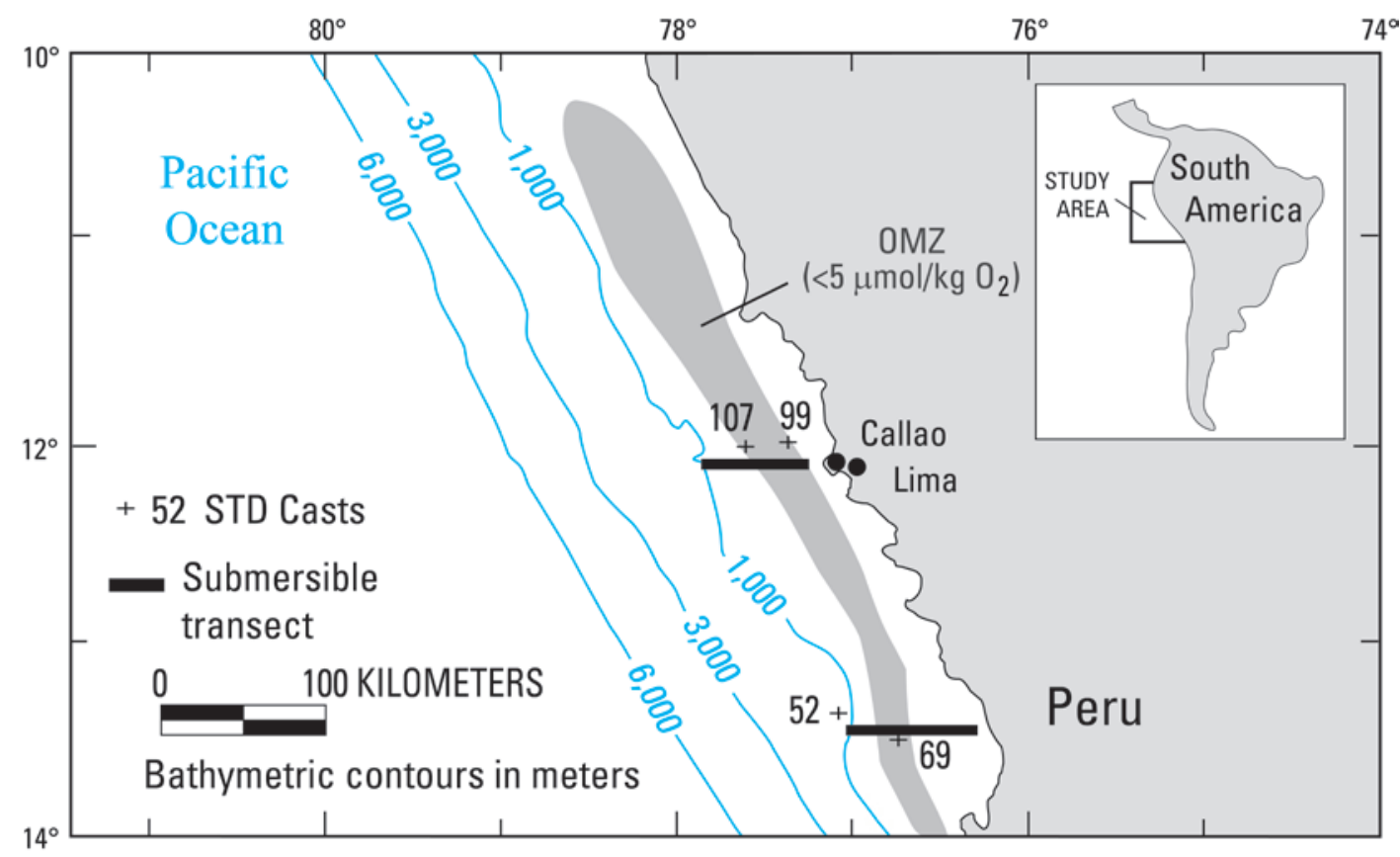

Figure 1. Map of the coast of Peru showing bathymetry (in meters); the average position of the oxygen minimum zone (OMZ; $<5$ micromoles per kilogram or $<1.0$ milligram per liter [parts per million] dissolved oxygen); the locations of selected salinity, temperature, and depth (STD) casts; and the locations of DS/V Johnson Sea-Link // submersible dive transects at $12^{\circ} \mathrm{S}$ and $13.5^{\circ} \mathrm{S}$ in October and November 1992.

The main objectives of this paper are (1) to examine the distribution and characteristics of surface sediments, particularly surface-sediment geochemistry and mineralogy, as a function of water depth, and (2) to relate these parameters to conditions resulting from prevailing oceanographic processes including DO concentrations, organic-matter flux, and bottom-current patterns. We emphasize the extensive early diagenesis at or just below the seafloor that is fueled by high fluxes of OC and low bottom-water DO content at the sediment-water interface. The rapid mobilization of iron and phosphorus as well as silica from the dissolution of biogenic opal leads to the formation of authigenic minerals at the surface. In addition, we recognize a surprisingly strong role of currents on slope sedimentation along the margin that results in winnowing and concentration of certain sediment components, as well as long sedimentexposure times at the seafloor across the upper slope. These currents and important redox reactions promote the occurrence of three major depth-related facies belts: (1) a shallow belt of OC-rich, calcareous and diatomaceous muds, relatively enriched in detrital clay minerals and stabilized by bacterial mats; (2) an intermediate-depth phosphatic facies, consisting primarily of grains, crusts and nodules of phosphorite, and some dolomite cemented crusts; and (3) a deeper region of glaucony sand. Though some authors prefer to restrict "glauconite" to the specific ironpotassium phyllosilicate (mica) mineral and use the term "glaucony" for the facies (Smith and others, 1998), we use the term "glaucony" for the mineral grains and the facies, as suggested by Odin (1985). Here, as in most other localities, glaucony occurs as sand-size, rounded aggregates of very fine-grained scaly particles. The dominant authigenic origin of sediments on the Peru margin and the importance of bottom currents on slope sedimentation have important implications for sediment accumulation on continental margins with strong OMZs. 


\section{Materials and Methods}

\section{Acquisition of Samples}

Samples of sediment in 36 box cores, 26 gravity cores, and 18 multicores deployed from the $R / V$ Seward Johnson and box and push cores deployed during 31 submersible dives with $D S / V$ Johnson Sea-Link II were collected for this investigation (Arthur and others, 1998). The submersible dives resulted in high-resolution video coverage of bottom operations, sediment types, and organisms and the recovery of 108 push cores, 32 pore-water cores, 25 small box cores, a large number of bottom-sediment slurp samples in buckets, and numerous samples of crusts, nodules, and other materials using the mechanical arm of the submersible. For this study of surface-sediment characteristics, we collected samples at intervals of $0-1 \mathrm{~cm}$ and $1-2 \mathrm{~cm}$ from most submersible-deployed push cores and at intervals of 0-2 cm from selected deck-deployed box cores. Bottom-current directions and velocities were measured from the submersible at numerous stations using an external current meter. Water-column salinity, temperature, depth, and DO profiles (fig. 2) were measured at numerous stations using a Seabird Electronics (SBE19) STD-DO system. Bottom reflectivity characteristics were monitored in some areas using a 33-kilohertz $(\mathrm{kHz})$ bottom profiling system on the $R / V$ Seward Johnson.

\section{Inorganic Geochemical Analyses}

Splits of surface-sediment samples from box and submersible push cores for geochemical analyses were air dried and ground in a ceramic mill to pass a 100-mesh sieve. Concentrations of 30 major, minor, and trace elements [aluminum $(\mathrm{Al})$, iron $(\mathrm{Fe})$, magnesium $(\mathrm{Mg})$, calcium $(\mathrm{Ca})$, sodium $(\mathrm{Na})$, potassium $(\mathrm{K})$, titanium $(\mathrm{Ti})$, phosphorus $(\mathrm{P})$, manganese $(\mathrm{Mn})$, arsenic $(\mathrm{As})$, barium $(\mathrm{Ba})$, cadmium $(\mathrm{Cd})$, cerium $(\mathrm{Ce})$, cobalt $(\mathrm{Co})$, chromium $(\mathrm{Cr})$, copper $(\mathrm{Cu})$, gallium $(\mathrm{Ga})$, lanthanum (La), lithium (Li), molybdenum (Mo), niobium $(\mathrm{Nb})$, neodymium $(\mathrm{Nd})$, nickel $(\mathrm{Ni})$, lead $(\mathrm{Pb})$, scandium $(\mathrm{Sc})$, strontium $(\mathrm{Sr})$, thorium $(\mathrm{Th})$, vanadium $(\mathrm{V})$, yttrium $(\mathrm{Y})$, and zinc $(\mathrm{Zn})]$ in 81 samples from the $13.5^{\circ} \mathrm{S}$ transect and 66 samples from the $12^{\circ} \mathrm{S}$ transect were determined by inductively coupled, argon-plasma, atomic emission spectrometry (ICP-AES; Briggs, 2002). Concentrations of 10 major elements [silicon ( $\mathrm{Si}$ ), Al, Fe, Mg, Ca, Na, K, Ti, P, and $\mathrm{Mn}]$ in 68 of the 81 samples from the $13.5^{\circ} \mathrm{S}$ transect were measured by wavelengthdispersive X-ray fluorescence spectrometry (XRF; Taggart and others, 1987). For most elements, the precision of the method, determined by analyzing U.S. Geological Survey rock standards and duplicating 10 percent of the samples, was better than 10 percent of the amount present and usually better than 5 percent of the amount present for elements in concentrations greater than 10 times the detection limit.

\section{Carbon Analyses}

Concentrations of total carbon (TC) and inorganic carbon (IC) were determined by coulometry (Engleman and others, 1985) in splits of the geochemistry samples. Carbonate in the untreated sample is reacted with phosphoric acid to liberate $\mathrm{CO}_{2}$, which is then titrated in a coulometer cell to measure inorganic carbon. Percent calcium carbonate $\left(\mathrm{CaCO}_{3}\right)$ is calculated by dividing percent $\mathrm{IC}$ by 0.12 , the fraction of $\mathrm{IC}$ in $\mathrm{CaCO}_{3}$. Total carbon is measured by liberating $\mathrm{CO}_{2}$ by combustion of an untreated sample at $1,050^{\circ} \mathrm{C}$ in a stream of oxygen and titrating the $\mathrm{CO}_{2}$. Concentrations of organic carbon (OC) were determined by the difference between TC and IC. The accuracy and precision for both TC and IC, determined from hundreds 
of replicate standards (reagent grade $\mathrm{CaCO}_{3}$ and a Cretaceous OC-rich marlstone), usually are better than 0.10 weight percent. Methods for characterization of Peru margin organic matter by Rock-Eval pyrolysis and carbon-isotope techniques have been presented in Arthur and others (1998).
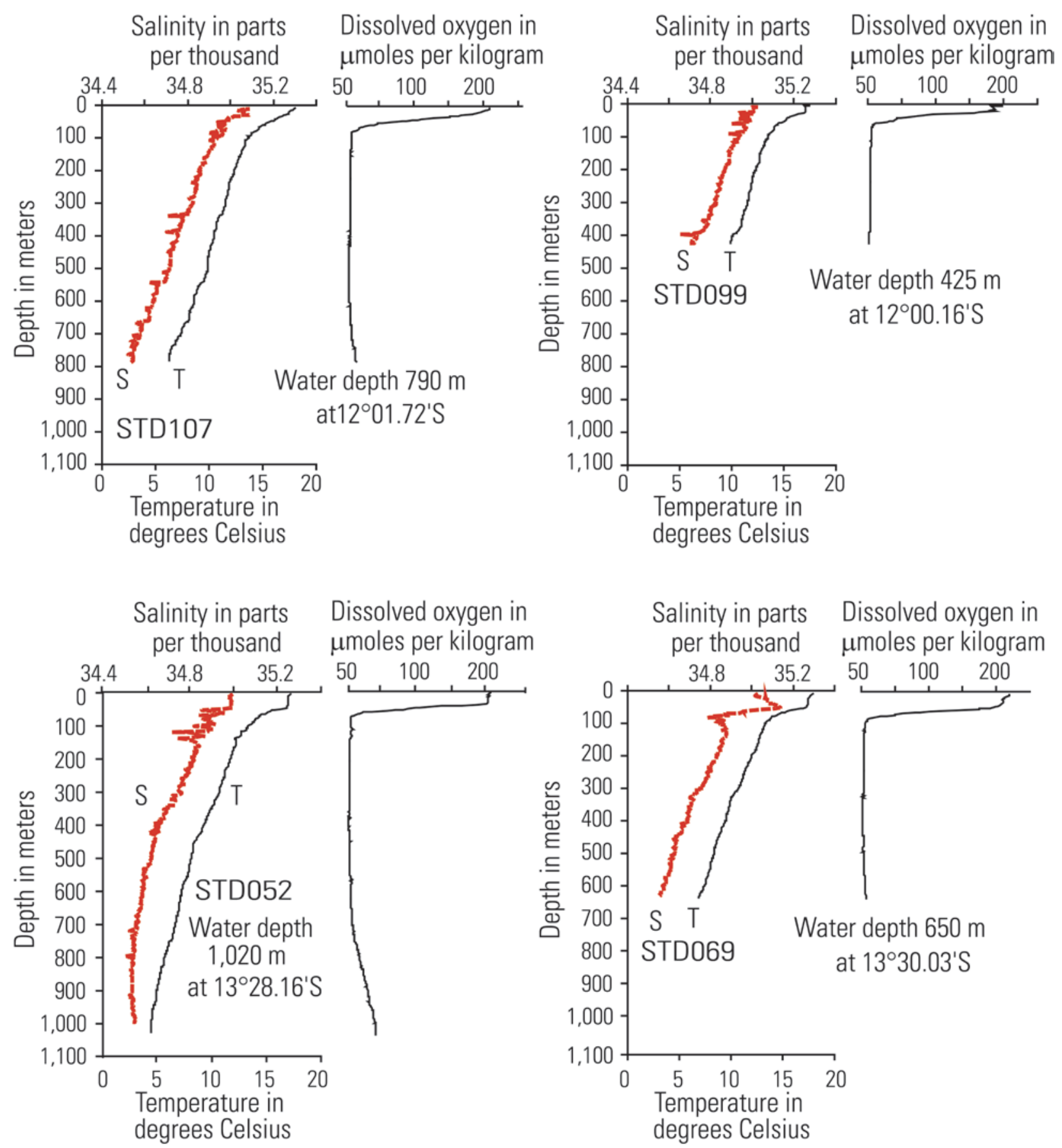

Figure 2. Representative salinity, temperature, depth, and dissolved oxygen (STD-DO) profiles taken at select locations on the $12^{\circ} \mathrm{S}$ and $13.5^{\circ} \mathrm{S}$ transects of the $R / V$ Seward Johnson expedition on the Peru continental margin. Only the longer profiles at the deeper sites (>750 meters) show the full extent of the oxygen minimum zone $(100-700 \mathrm{~m})$. 


\section{Factor Analyses}

In order to determine what elements are associated with specific sediment components, multivariate analysis of the inorganic geochemical data and the $\mathrm{OC}$ and IC for each transect was analyzed by multivariate Q-mode factor analysis. In addition, Q-mode analysis objectively determines geographic groupings of samples across each of the transects based on geochemical similarities. The computer program used is a modified version of the extended CABFAC program described by Klovan and Miesch (1976). All samples (0-2 cm in box cores, $0-1 \mathrm{~cm}$ and $1-2 \mathrm{~cm}$ in push cores) were used for the Q-mode factor analyses. However, because the values for geochemical concentrations ranged widely, from fractions of a percent to thousands of parts per million ( $\mathrm{ppm}$ ), each value for a variable was scaled prior to analysis to a fraction of each variable's range. Thus the scaled values ranged from 0 to 1 . The factor analyses essentially reduced 32 geochemical variables to $4\left(13.5^{\circ} \mathrm{S}\right.$ transect $)$ or $3\left(12^{\circ} \mathrm{S}\right.$ transect $)$ composite geochemical variables, or factor loadings, that explained most of the variance in the scaled data. To determine what geochemical variables had the most influence on each factor, the factor loadings (composite variables) were correlated with the concentration of each element. The results of these correlation analyses are given in table 1 for the $12^{\circ} \mathrm{S}$ transect and table 2 for the $13.5^{\circ} \mathrm{S}$ transect.

\section{Characteristics of the Water Column and Distribution of Biota}

Casts for STD-DO (fig. 2) indicate that DO concentrations were similar along both transects, ranging from greater than $(>) 200$ micromoles per kilogram $(\mu \mathrm{M})$ in surface waters to less than $(<) 5 \mu \mathrm{M}$ (essentially zero according to calibrations on board ship using microwinkler titrations) within the OMZ (fig. 2). The top of the OMZ in October-November 1992 was at $<50$ $\mathrm{m}$ on the shelf in water depths $<100 \mathrm{~m}$, and at about $100 \mathrm{~m}$ over the slope (fig. 2). The bottom of the OMZ ( $>5 \mu \mathrm{M}$ DO) typically was at about $700 \mathrm{~m}$ over the slope.

Persistent, high-velocity bottom currents (up to 30 centimeters per second $[\mathrm{cm} / \mathrm{s}]$ ) characterize much of the Peru slope. The strongest currents measured in this study were associated with the southward (poleward) flowing Peru Countercurrent and were most persistent on the upper slope between about 150 and $300 \mathrm{~m}$ (fig. 3). Current directions and magnitudes were more variable on the shelf and lower part of the upper slope. Also, current magnitudes and directions were much more variable on the $12^{\circ} \mathrm{S}$ transect (fig. $3 \mathrm{~A}$ ) than on the $13.5^{\circ} \mathrm{S}$ transect (fig. $3 B$ ). There was a minor influence of the northward flowing surface Peru Current on the shallow shelf on both transects (fig. $3 A$ and $B$ ). The strongest currents occurred on the upper slope at depths of $200-250 \mathrm{~m}$ on the $12^{\circ} \mathrm{S}$ transect (fig. $3 A$ ) and $150-250 \mathrm{~m}$ on the $13.5^{\circ} \mathrm{S}$ transect (fig. 3B). Submersible observations showed that these upper-slope depths were characterized by very high concentrations of particulates in the water column and traction transport of larger particles on the seafloor. 

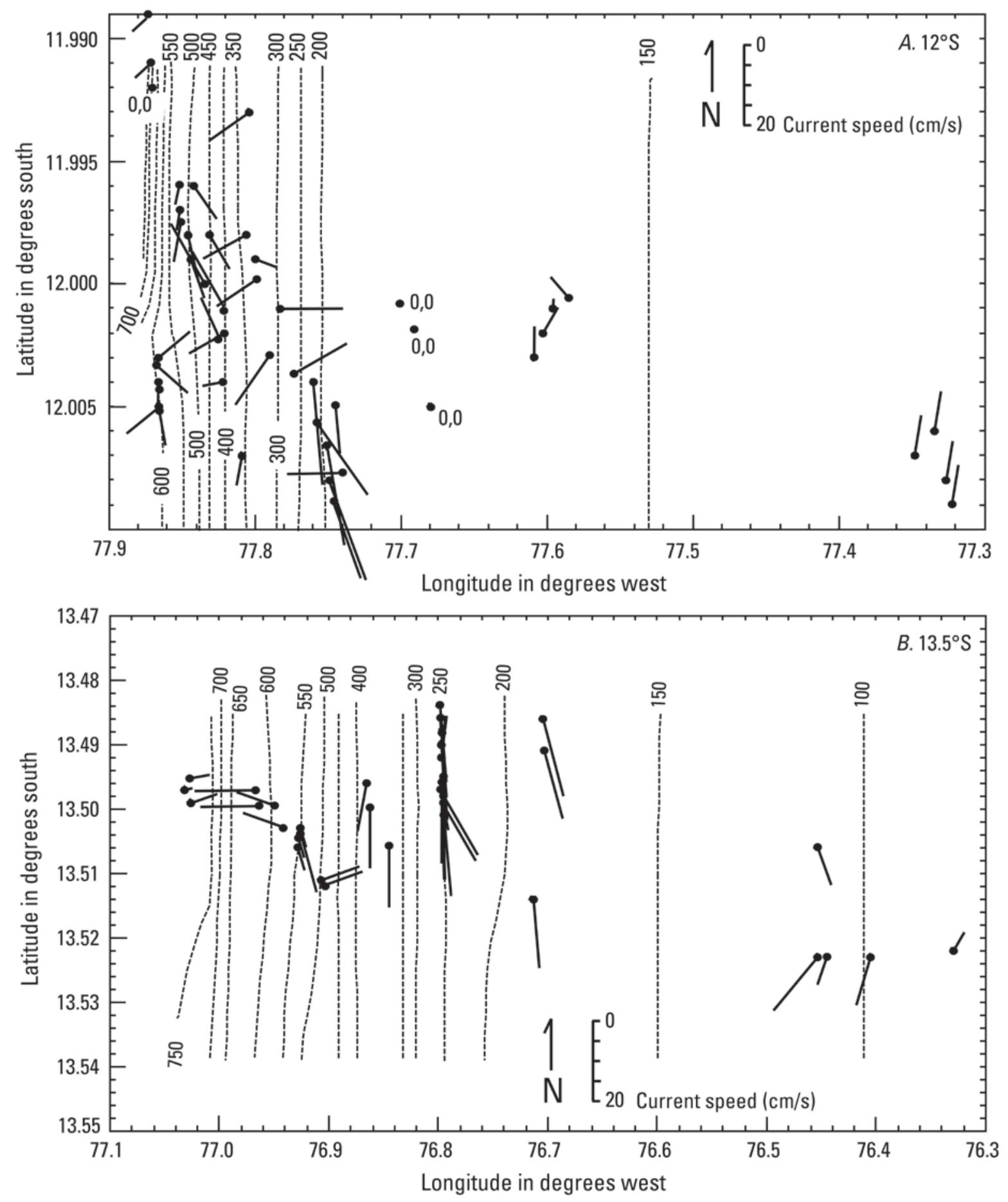

Figure 3. Map of bathymetry and bottom-current measurements made along two dive transects on the Peru margin. $A, 12^{\circ} \mathrm{S}$ transect, October 27-November 5, 1992. B, 13.5 ${ }^{\circ} \mathrm{S}$ transect, October 15-25, 1992. Bathymetric contour interval (dashed line) is 50 meters. Each black dot represents a measurement of the current. The length of the bar radiating from each dot is proportional to the speed of the current in centimeters per second $(\mathrm{cm} / \mathrm{s}$; see scale), and the azimuth of the bar is the direction of the current. $0,0=$ zero speed, zero direction. 
A variety of fish, octopi, crabs, and other organisms were observed in the water column near the top and bottom of the intense midwater OMZ. High concentrations of euphausiids were observed consistently near the top of the OMZ on both transects, even at DO concentrations of 5-10 $\mu \mathrm{M}$. These dense concentrations of euphausiids commonly were observed on the $33 \mathrm{kHz}$ "fish finder" records. Relatively few benthic metazoans were observed on the inner shelf (70$100 \mathrm{~m}$ ) where the sediment surface commonly was covered by thick, white mats of Thioploca (sulfide-oxidizing bacteria). Abundant polychaete worms occurred in the upper few centimeters of sediment on the inner shelf. No benthic metazoans were observed at water depths of 150-350 $\mathrm{m}$ on the upper slope, indicating that low DO concentrations in the core of the OMZ apparently limit the occurrence of benthic organisms. However, even though DO concentrations remained low $(<5 \mu \mathrm{M}$ to water depths of as much as $700 \mathrm{~m}$, the abundance and diversity of organisms increased substantially below $350 \mathrm{~m}$, and was very high at depths below $700 \mathrm{~m}(>10 \mu \mathrm{M} \mathrm{DO})$. Thioploca mats and polychaete worms, when they were present, inhabited the upper $5 \mathrm{~cm}$ or more of surface muds at these deeper mid-slope sites. Well-developed laminations were rarely observed in submersible- or deck-deployed cores, even though no molluscs or other large burrowing organisms were present. Fossil and living benthic foraminifera were very abundant, however, and often were concentrated at the surface as a winnowed lag deposit.

\section{Lithofacies Distributions}

Green-gray to dark olive-gray gelatinous, calcareous, diatomaceous muds are characteristic of surface sediments on the Peru outer shelf and upper slope. Phosphorite crusts begin as layers of sediment just below the sediment-water interface that are weakly cemented by CFA and less commonly by dolomite with polychaete worm burrows still preserved ("protocrusts"; fig. 4A). Layers of protocrust were observed from the submersible cropping out on the seafloor where they had been undercut by bottom currents. With time, the protocrusts become completely cemented and most of the polychaete burrows are filled with CFA (fig. $4 B$ ). The crusts are periodically broken up by the activity of organisms and bottom currents and are recemented to form mature phosphorite pavements (fig. 4C).

On the $12^{\circ} \mathrm{S}$ transect, phosphorite nodules and crusts were observed between about 200 and $500 \mathrm{~m}$ (fig. $5 A$ ) and extensive phosphorite pavements from $500 \mathrm{~m}$ to at least $700 \mathrm{~m}$. Phosphorite nodules, crusts, and pavements were found on the $13.5^{\circ} \mathrm{S}$ transect from about $150 \mathrm{~m}$ to $600 \mathrm{~m}$ (fig. $5 B$ ). The deeper regions of the upper slope on the $13.5^{\circ} \mathrm{S}$ transect, sampled down to $1,050 \mathrm{~m}$, typically were composed of homogeneous glauconitic sands, silts, and muds (fig. $5 B$ ). 


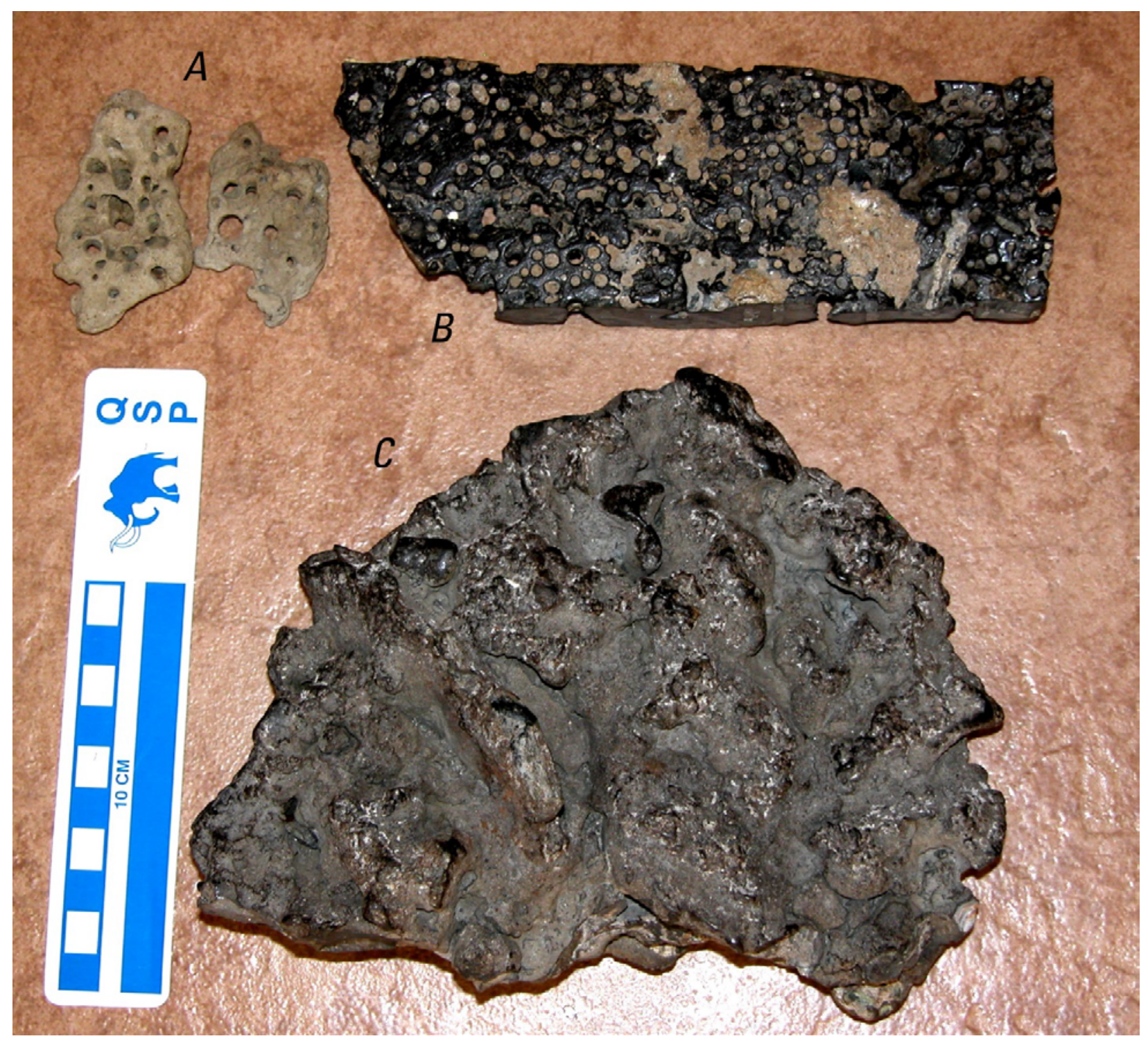

Figure 4. Examples of the progressive formation of phosphorite crusts and pavements on the Peru margin. $A$, Weakly cemented sediment (protocrust) with uncemented polychaete worm burrows. $B$, Strongly cemented slab of phosphorite with black manganese oxide coating and mostly filled and cemented polychaete worm burrows. $C$, Mature phosphorite pavement composed of broken fragments of well-cemented phosphorite crust that have been recemented. 

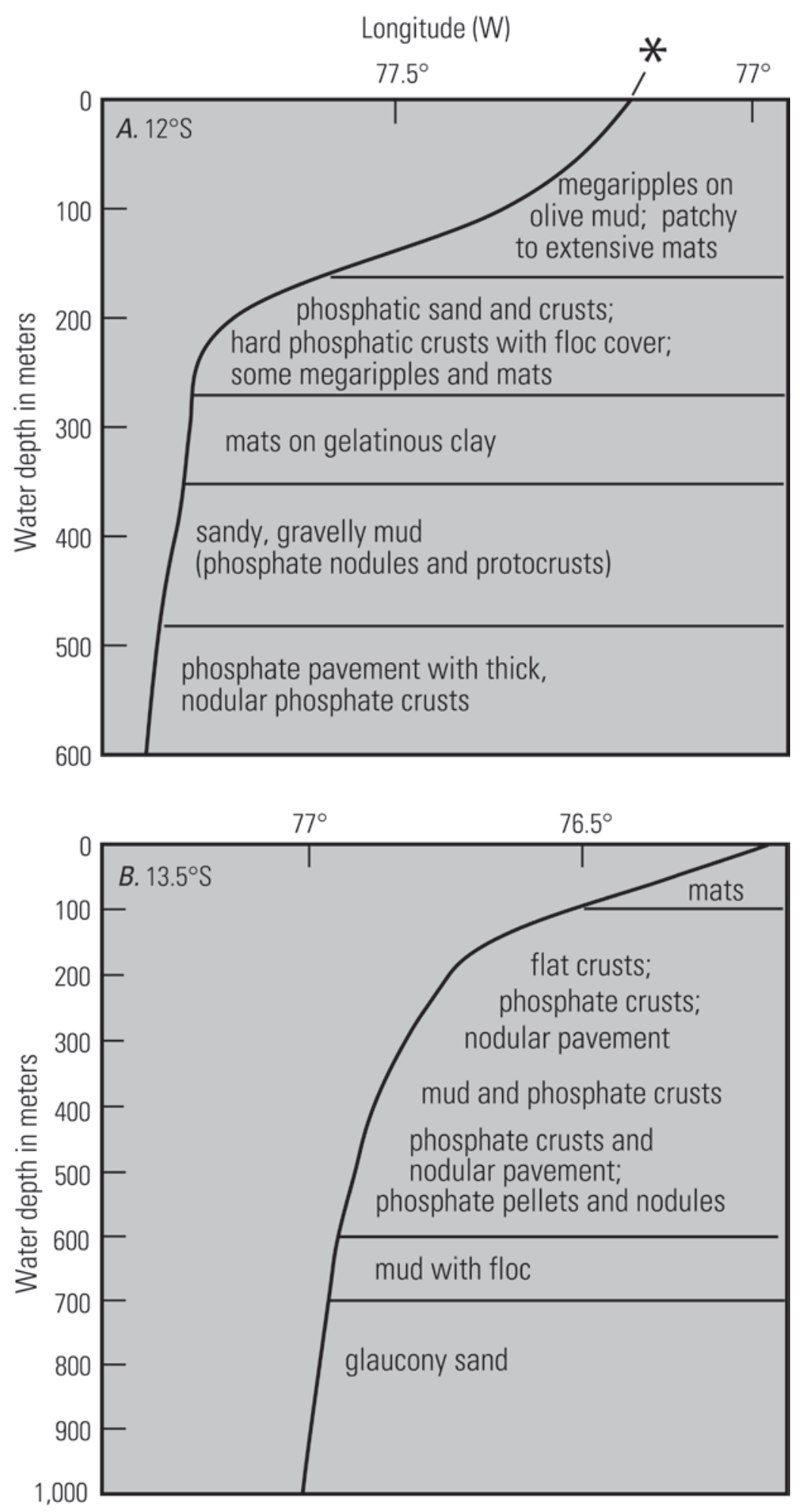

Figure 5. Cross sections showing the lithology and characteristics of surface sediments as a function of water depth along two transects on the Peru margin. $A, 12^{\circ} \mathrm{S}$ transect. $B, 13.5^{\circ} \mathrm{S}$ transect. Star shows the location of Callao, Peru. 


\section{Geochemical Facies Distributions}

\section{Results from the $12^{\circ} \mathrm{S}$ Transect}

Table 1 shows that concentrations of $\mathrm{OC}, \mathrm{Ni}, \mathrm{V}, \mathrm{Cd}, \mathrm{Mo}, \mathrm{Cu}, \mathrm{Na}, \mathrm{Cr}, \mathrm{Zn}$, and $\mathrm{Co}$, in order of decreasing correlation coefficient between element concentration and factor 1 loadings, had the most influence in grouping samples from the $12^{\circ} \mathrm{S}$ transect into factor 1 . These OC- and $\mathrm{CaCO}_{3}$-rich, factor 1 sediments occur on the outer shelf and upper slope between about 150 and $400 \mathrm{~m}$ (figs. $6 A$ and $C$; fig. 7A). Factor 1 accounted for 67 percent of the variance in the scaled data.

Grouping of samples into factor 2 was influenced mostly by $\mathrm{Sr}, \mathrm{Ca}, \mathrm{P}$, and IC, in order of deceasing correlation coefficients between element concentration and factor 2 loadings (table 1). The higher concentrations of these elements in factor 2 sediments are the result of higher amounts of CFA. The elements $\mathrm{Ca}, \mathrm{P}$, and IC are part of the main structure of CFA; Sr substitutes for $\mathrm{Ca}$ in the crystal lattice. Factor 2 sediments are concentrated in a band between about 350 and $750 \mathrm{~m}$ (fig. $7 \mathrm{~B}$ ), down slope from the band of factor 1 sediments. Factor 2 accounted for 17 percent of the variance in the scaled data.

Factor 3 sediments have the highest content of detrital clastic material (aluminosilicates) undiluted by either organic matter (as in factor 1 sediments) or CFA (as in factor 2 sediments). Concentrations of many elements influenced the grouping of samples into factor 3; most important were the lithophile elements Fe, Al, Ga, Th, Ti, Li, Sc, Ce, Nb, K, Nd, As, Mn, La, Zn, and $\mathrm{Pb}$, in order of decreasing correlation coefficients between element concentration and factor 3 loadings (table 1). Factor 3 sediments mostly occur at depths $>750 \mathrm{~m}$, below the zones of sediments enriched in organic matter and CFA (fig. $7 C$ ). Figure $7 C$ shows that a few samples with factor 3 characteristics occur at $100 \mathrm{~m}$ and 400-500 m. Factor 3 accounted for 8 percent of the variance in the scaled data.

Grouping samples into factor 4 was based mainly on concentrations of $\mathrm{Na}$ and $\mathrm{Mg}$ (table 1), probably due to concentrations of these elements precipitated as sea salts from interstitial seawater during drying because the sediments were not washed before being analyzed. Therefore, factor 4 loadings are not plotted in Figure 7. Note that these two elements also make minor contributions to factor 1 (table 1) because OC-rich sediments usually have higher porosities and, therefore, higher sea-salt concentrations when dried. 
Table 1. Correlation coefficients between loadings for factors 1-4 and concentrations of major elements (in weight percent) and trace elements (in parts per million) in surface sediments on the $12^{\circ} \mathrm{S}$ transect. Correlation coefficients in bold type indicate those elements that had the most influence in determining each factor.

\begin{tabular}{lrrrr}
\hline \multicolumn{1}{c}{ Element } & Factor 1 & Factor 2 & Factor 3 & Factor 4 \\
\hline Aluminum & -0.02 & -0.33 & $\mathbf{0 . 9 3}$ & -0.44 \\
Calcium & -0.66 & $\mathbf{0 . 9 2}$ & -0.30 & -0.52 \\
Iron & -0.19 & -0.11 & $\mathbf{0 . 9 4}$ & -0.44 \\
Potassium & 0.11 & -0.51 & $\mathbf{0 . 8 0}$ & 0.07 \\
Magnesium & 0.45 & -0.59 & -0.15 & $\mathbf{0 . 8 8}$ \\
Sodium & $\mathbf{0 . 5 3}$ & -0.58 & -0.34 & $\mathbf{0 . 9 0}$ \\
Phosphorus & -0.61 & $\mathbf{0 . 9 2}$ & -0.26 & -0.56 \\
Titanium & 0.05 & -0.52 & $\mathbf{0 . 9 0}$ & -0.19 \\
Manganese & -0.18 & -0.33 & $\mathbf{0 . 6 6}$ & -0.36 \\
Arsenic & 0.31 & -0.44 & $\mathbf{0 . 7 6}$ & -0.15 \\
Barium & 0.02 & 0.13 & 0.31 & -0.11 \\
Cadmium & $\mathbf{0 . 9 1}$ & -0.51 & -0.07 & 0.18 \\
Cerium & -0.32 & -0.13 & $\mathbf{0 . 8 3}$ & -0.55 \\
Cobalt & $\mathbf{0 . 5 1}$ & -0.24 & 0.14 & -0.24 \\
Chromium & $\mathbf{0 . 5 2}$ & -0.12 & 0.03 & -0.57 \\
Copper & $\mathbf{0 . 8 4}$ & -0.62 & 0.23 & 0.16 \\
Gallium & -0.05 & -0.29 & $\mathbf{0 . 9 2}$ & -0.38 \\
Lanthanum & -0.41 & 0.04 & $\mathbf{0 . 6 5}$ & -0.67 \\
Lithium & 0.17 & -0.43 & $\mathbf{0 . 8 6}$ & -0.16 \\
Molybdenum & $\mathbf{0 . 8 9}$ & -0.55 & 0.03 & 0.22 \\
Niobium & 0.28 & -0.57 & $\mathbf{0 . 8 2}$ & -0.21 \\
Neodymium & -0.44 & 0.20 & $\mathbf{0 . 6 9}$ & -0.75 \\
Nickel & $\mathbf{0 . 9 4}$ & -0.52 & -0.22 & 0.17 \\
Lead & 0.33 & -0.53 & $\mathbf{0 . 5 2}$ & 0.16 \\
Scandium & -0.07 & -0.25 & $\mathbf{0 . 8 6}$ & -0.47 \\
Strontium & -0.64 & $\mathbf{0 . 9 5}$ & -0.27 & -0.54 \\
Thorium & -0.27 & -0.24 & $\mathbf{0 . 9 0}$ & -0.29 \\
Vanadium & $\mathbf{0 . 9 2}$ & -0.50 & -0.03 & 0.04 \\
Yttrium & -0.37 & 0.18 & 0.06 & -0.54 \\
Zinc & $\mathbf{0 . 5 2}$ & -0.56 & $\mathbf{0 . 5 5}$ & 0.03 \\
Inorganic carbon & -0.46 & $\mathbf{0 . 3 0}$ & -0.28 & -0.14 \\
Organic carbon & $\mathbf{0 . 9 5}$ & -0.56 & -0.24 & 0.37 \\
\hline & & & & \\
\hline
\end{tabular}



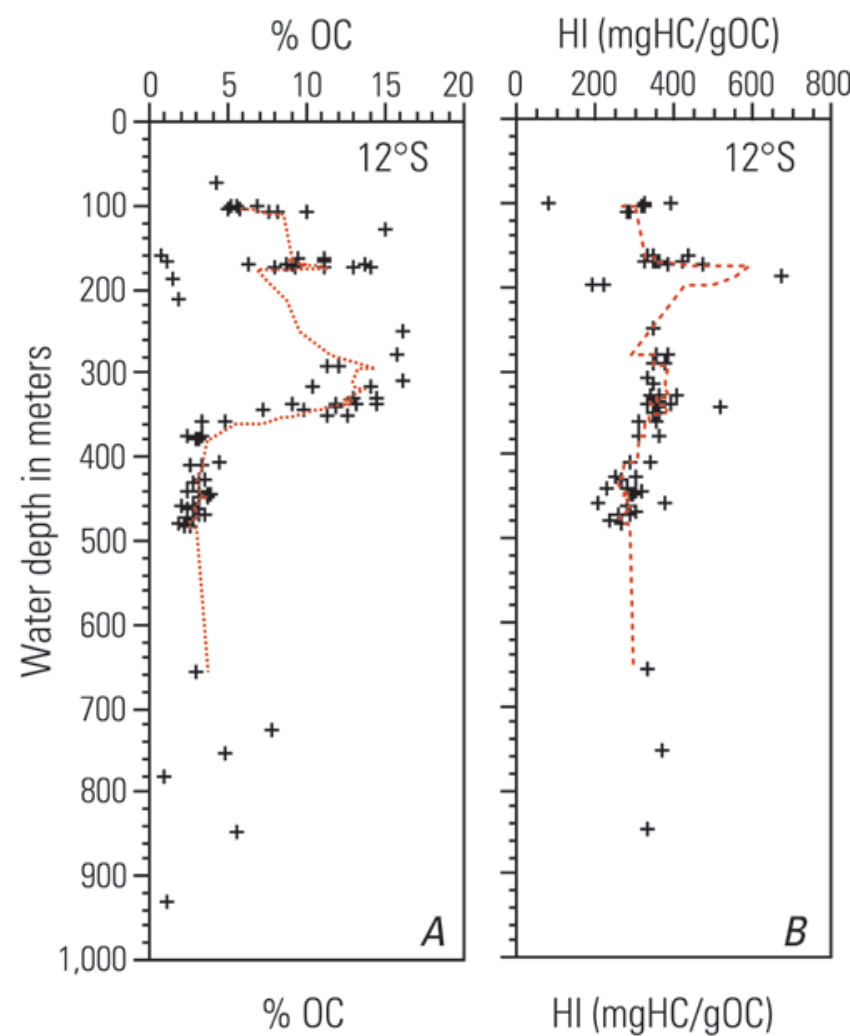

$\% \mathrm{CaCO}_{3}$-Calcite
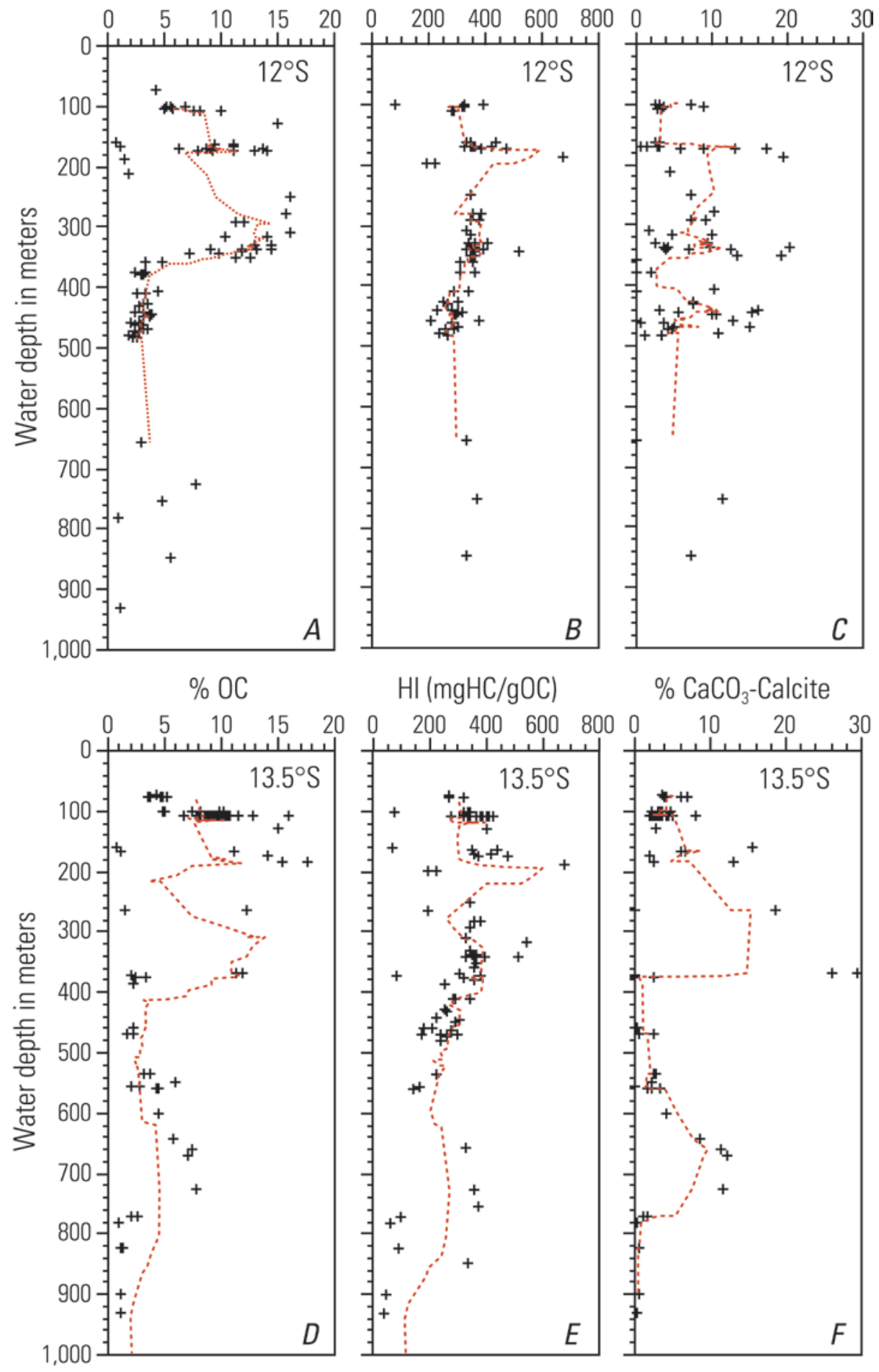

$\mathrm{HI}$ (mgHC/gOC)
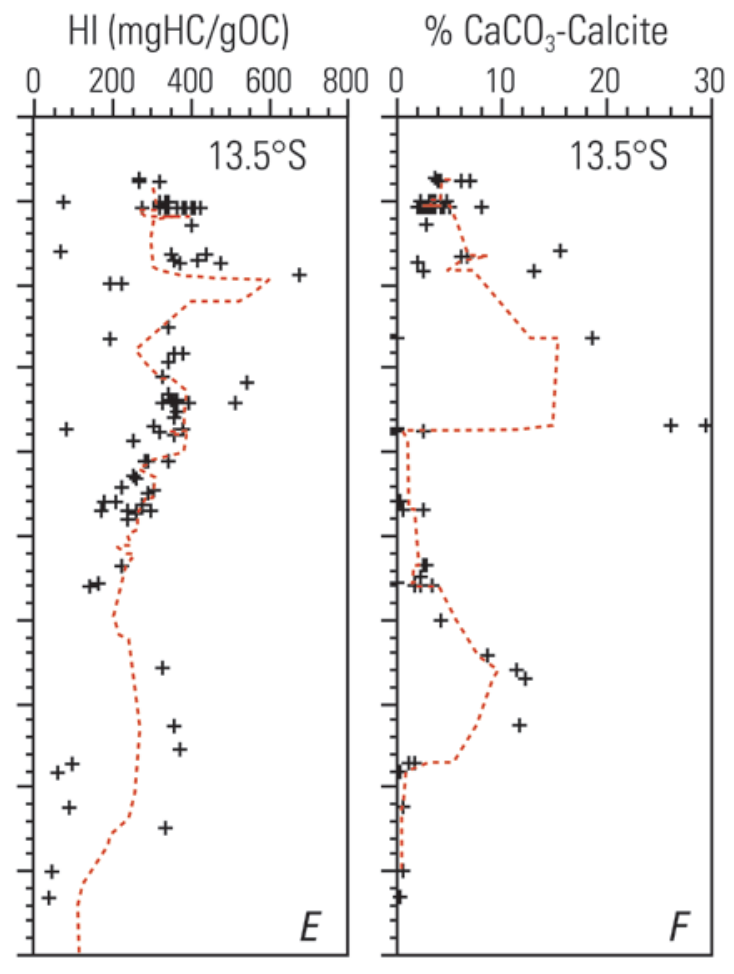

Figure 6. Plots of concentration of percent organic carbon (\% OC), Rock-Eval pyrolysis hydrogen index $(\mathrm{HI})$ in milligrams hydrocarbon per gram organic carbon $(\mathrm{mgHC} / \mathrm{gOC})$, and percent calculated $\mathrm{CaCO}_{3^{-}}$ calcite (see text for method of calculation) in surface sediments versus water depth along two transects on the Peru margin. $A-C, 12^{\circ} S$ transect. $D-F, 13.5^{\circ} S$ transect. Dashed red lines are 5-point moving averages of the data. 


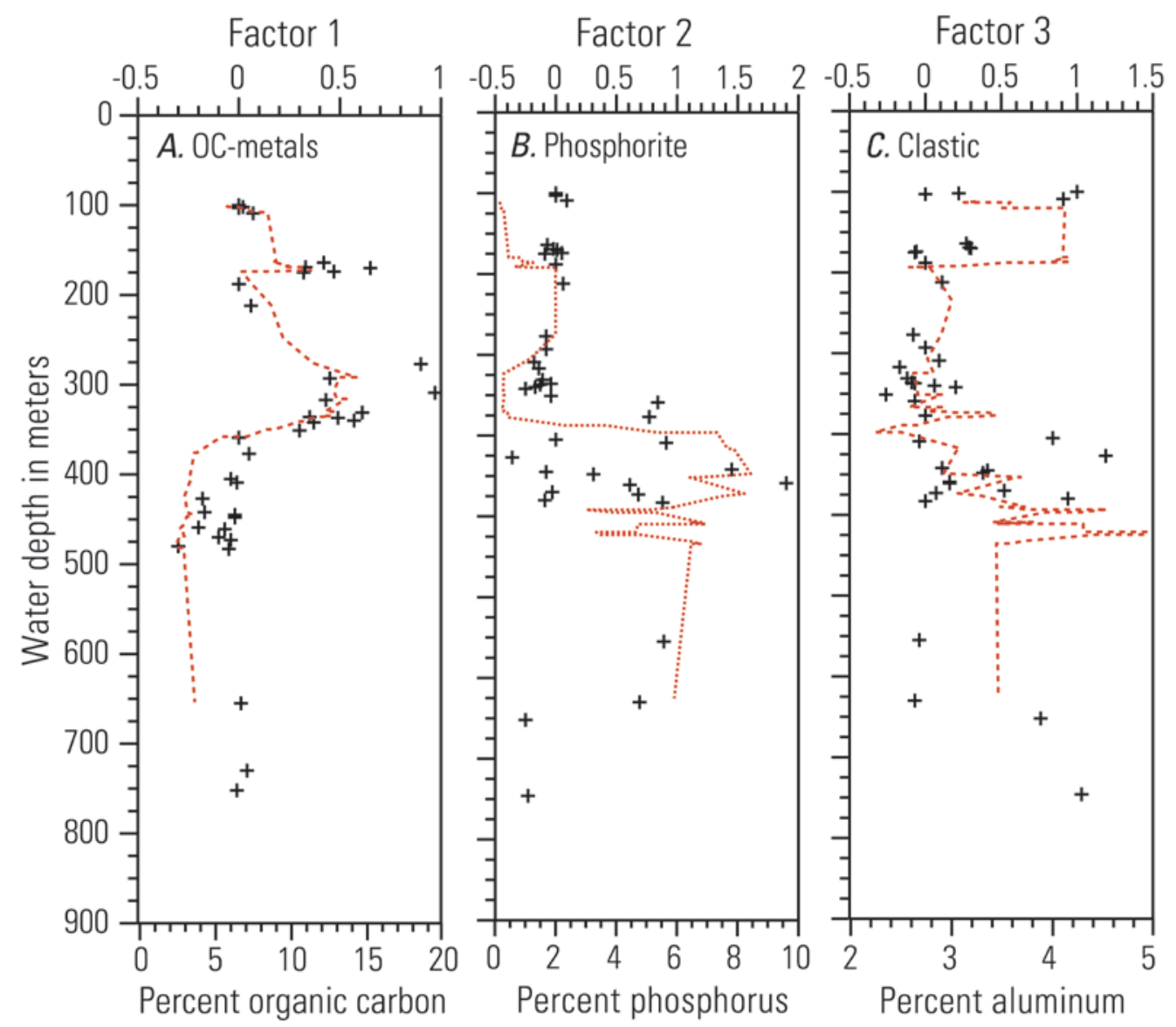

Figure 7. Plots of factor loadings versus water depth along the $12^{\circ} \mathrm{S}$ transect for (A) factor 1 , organic carbon and metals, (B) factor 2, phosphorite, and (C) factor 3, clastic, from Q-mode factor analysis of chemical composition of surface sediments. Dashed red lines are 5-point moving averages of the elemental data. 


\section{Results from the $13.5^{\circ} \mathrm{S}$ Transect}

Factor 1 sediments on the $13.5^{\circ} \mathrm{S}$ transect have characteristics similar to those of factor 1 sediments on the $12^{\circ} \mathrm{S}$ transect, with high concentrations of $\mathrm{OC}, \mathrm{Cd}, \mathrm{Mo}$, and several other trace metals (table 2). The OC- and metal-rich factor 1 sediments on the $13.5^{\circ} \mathrm{S}$ transect are concentrated mainly on the inner shelf at about $100 \mathrm{~m}$ with a zone of lesser factor 1 loadings between 550 and $700 \mathrm{~m}$ (fig. 8A). In contrast, the OC- and metal-rich factor 1 sediments on the $12^{\circ} \mathrm{S}$ transect are on the outer shelf and upper slope between 150 and $300 \mathrm{~m}$ (fig. $7 A$ ). These inner shelf sediments contain OC concentrations as high as 17 percent (fig. $6 B$ ). Concentrations of OC in the 550-700 m slope zone are mostly $<10$ percent, but this zone also contains elevated concentrations of $\mathrm{CaCO}_{3}$ (fig. $6 B$ ). Factor 1 accounted for 72 percent of the variance in the scaled data.

Grouping of samples into factor 2 was influenced primarily by $\mathrm{Fe}, \mathrm{K}, \mathrm{Cr}$, and $\mathrm{Mg}$, in order of deceasing correlation coefficients between element concentration and factor 2 loadings (table 2). The higher concentrations of the elements making up factor 2 (table 3 ) occur because these sediments contain high concentrations of glaucony, mainly as sand-sized aggregates of authigenic, micaceous clay minerals. These glaucony-rich factor 2 sediments are mainly found on the slope from $550 \mathrm{~m}$ to at least $1,067 \mathrm{~m}$ (the deepest sample) (fig. 8B), although samples with relatively high loadings for factor 2 are also found on the inner shelf at about $100 \mathrm{~m}$. Factor 2 accounted for 11 percent of the variance in the scaled data.

Glaucony is predominantly a $\mathrm{K}, \mathrm{Na}, \mathrm{Fe}, \mathrm{Mg}$ aluminosilicate with an approximate formula of $(\mathrm{K}, \mathrm{Na})\left(\mathrm{Fe}^{3+}, \mathrm{Al}, \mathrm{Mg}\right)_{2}(\mathrm{Si}, \mathrm{Al})_{4} \mathrm{O}_{10}(\mathrm{OH})_{2}$. The dominant cation in glauconite is $\mathrm{Fe}$, and an estimate of the percentage of glaucony in surface sediments on the $13.5^{\circ} \mathrm{S}$ transect can be obtained by subtracting out the amount of Fe in the detrital fraction, assuming that the detrital fraction contains the same element concentrations as average upper continental crust, and assuming that the iron present in excess of the detrital Fe is in glaucony (fig. $9 \mathrm{~A}$ ). A similar calculation also can be made for detrital and excess K (fig. 9B). There are excellent correlations between $\mathrm{Fe}$ and $\mathrm{Al}$ and between $\mathrm{K}$ and $\mathrm{Al}$ for samples between 100 and $400 \mathrm{~m}$ on the $13.5^{\circ} \mathrm{S}$ transect where there is little glaucony (fig. $8 B$ ). For these samples, we assume that all of the Fe and $\mathrm{K}$ is in the detrital fraction and that the detrital fraction has the composition of upper continental crust. The regression equations for these samples are $\% \mathrm{Fe}=0.48 \% \mathrm{Al}-0.028, \mathrm{r}=0.943$ (fig. $9 A$ ) and $\% \mathrm{~K}=0.23 \% \mathrm{Al}-0.335, \mathrm{r}=0.930$ (fig. $9 B$ ). Assuming that the slope of the ironaluminum regression equation $(0.48)$ is the ratio of iron to aluminum in the detrital fraction, the concentration of "detrital Fe" can be calculated by multiplying the aluminum concentration by 0.48 , close to the Fe/Al ratio in upper continental crust (0.45; Wedepohl, 1995) (fig. 9A). The concentration of "excess Fe" (assumed to be glaucony Fe) can be calculated as the difference between total $\mathrm{Fe}$ and detrital $\mathrm{Fe}$. Chemical analysis of relatively pure glaucony sand in box cores $\mathrm{BC} 50$ and $\mathrm{BC} 43$ from the western end of the $13.5^{\circ} \mathrm{S}$ transect $\left(>77^{\circ} \mathrm{W}\right.$ longitude; water depths $>750 \mathrm{~m}$ ) support this calculation. For example, the concentrations of $\mathrm{Fe}, \mathrm{K}$, and $\mathrm{Mg}$ in glaucony in sediments from BC50 and BC43 are very similar to those in the factor 2 end-member sediment sample and are very different from the other end-member sediments (table 3). End-member glaucony contains about $20 \% \mathrm{Fe}, 5 \% \mathrm{~K}$, and $2 \% \mathrm{Mg}$ (table 3; fig. 9). Using 20\% excess $\mathrm{Fe}$ as an end member, the amount of glaucony in any sample can be determined by the amount of excess Fe in that sample. The average percent glaucony in all samples is 15.6 percent, range $0-100$ percent. 
Table 2. Correlation coefficients between loadings for factors $1-4$ and concentrations of major elements (in weight percent) and trace elements (in parts per million) in surface sediments on the $13.5^{\circ} \mathrm{S}$ transect. Correlation coefficients in bold type indicate those elements that had the most influence in determining each factor.

\begin{tabular}{lrrrr}
\hline \multicolumn{1}{c}{ Element } & Factor 1 & Factor 2 & Factor 3 & Factor 4 \\
\hline Aluminum & 0.45 & -0.61 & -0.57 & $\mathbf{0 . 9 2}$ \\
Calcium & -0.47 & -0.13 & $\mathbf{0 . 9 7}$ & -0.38 \\
Iron & -0.60 & $\mathbf{0 . 9 7}$ & -0.03 & -0.28 \\
Potassium & -0.56 & $\mathbf{0 . 9 7}$ & -0.13 & -0.16 \\
Magnesium & -0.02 & $\mathbf{0 . 5 1}$ & -0.55 & 0.12 \\
Sodium & $\mathbf{0 . 8 9}$ & -0.67 & -0.56 & 0.15 \\
Phosphorus & -0.49 & -0.07 & $\mathbf{0 . 9 5}$ & -0.38 \\
Titanium & 0.40 & -0.51 & -0.62 & $\mathbf{0 . 9 4}$ \\
Manganese & 0.52 & -0.66 & -0.57 & $\mathbf{0 . 8 7}$ \\
Arsenic & -0.14 & -0.17 & 0.34 & 0.10 \\
Barium & 0.58 & -0.71 & -0.53 & $\mathbf{0 . 7 6}$ \\
Cadmium & $\mathbf{0 . 9 4}$ & -0.67 & -0.50 & 0.15 \\
Cerium & 0.20 & -0.61 & -0.21 & $\mathbf{0 . 8 8}$ \\
Cobalt & 0.28 & -0.37 & -0.29 & $\mathbf{0 . 5 5}$ \\
Chromium & -0.60 & $\mathbf{0 . 8 7}$ & 0.18 & -0.31 \\
Copper & $\mathbf{0 . 7 9}$ & -0.51 & -0.71 & $\mathbf{0 . 5 3}$ \\
Gallium & -0.02 & 0.13 & -0.59 & $\mathbf{0 . 8 1}$ \\
Lanthanum & -0.07 & -0.45 & 0.19 & $\mathbf{0 . 6 5}$ \\
Lithium & 0.41 & -0.39 & -0.65 & $\mathbf{0 . 8 8}$ \\
Molybdenum & $\mathbf{0 . 9 1}$ & -0.63 & -0.52 & 0.19 \\
Niobium & 0.51 & -0.52 & -0.56 & $\mathbf{0 . 7 2}$ \\
Neodymium & -0.13 & -0.40 & -0.04 & $\mathbf{0 . 7 9}$ \\
Nickel & 0.41 & -0.30 & 0.10 & -0.27 \\
Lead & 0.31 & -0.26 & 0.29 & 0.29 \\
Scandium & -0.05 & 0.05 & -0.42 & $\mathbf{0 . 7 9}$ \\
Strontium & -0.44 & -0.17 & $\mathbf{0 . 9 6}$ & -0.33 \\
Thorium & 0.19 & -0.35 & -0.52 & $\mathbf{0 . 9 3}$ \\
Vanadium & $\mathbf{0 . 8 3}$ & -0.44 & -0.41 & 0.03 \\
Yttrium & -0.49 & 0.07 & $\mathbf{0 . 6 8}$ & -0.04 \\
Zinc & $\mathbf{0 . 6 7}$ & -0.54 & -0.69 & $\mathbf{0 . 7 0}$ \\
Inorganic carbon & -0.27 & -0.13 & $\mathbf{0 . 6 2}$ & -0.32 \\
Organic carbon & $\mathbf{0 . 8 8}$ & -0.58 & -0.46 & 0.04 \\
\hline & & & & \\
\hline
\end{tabular}



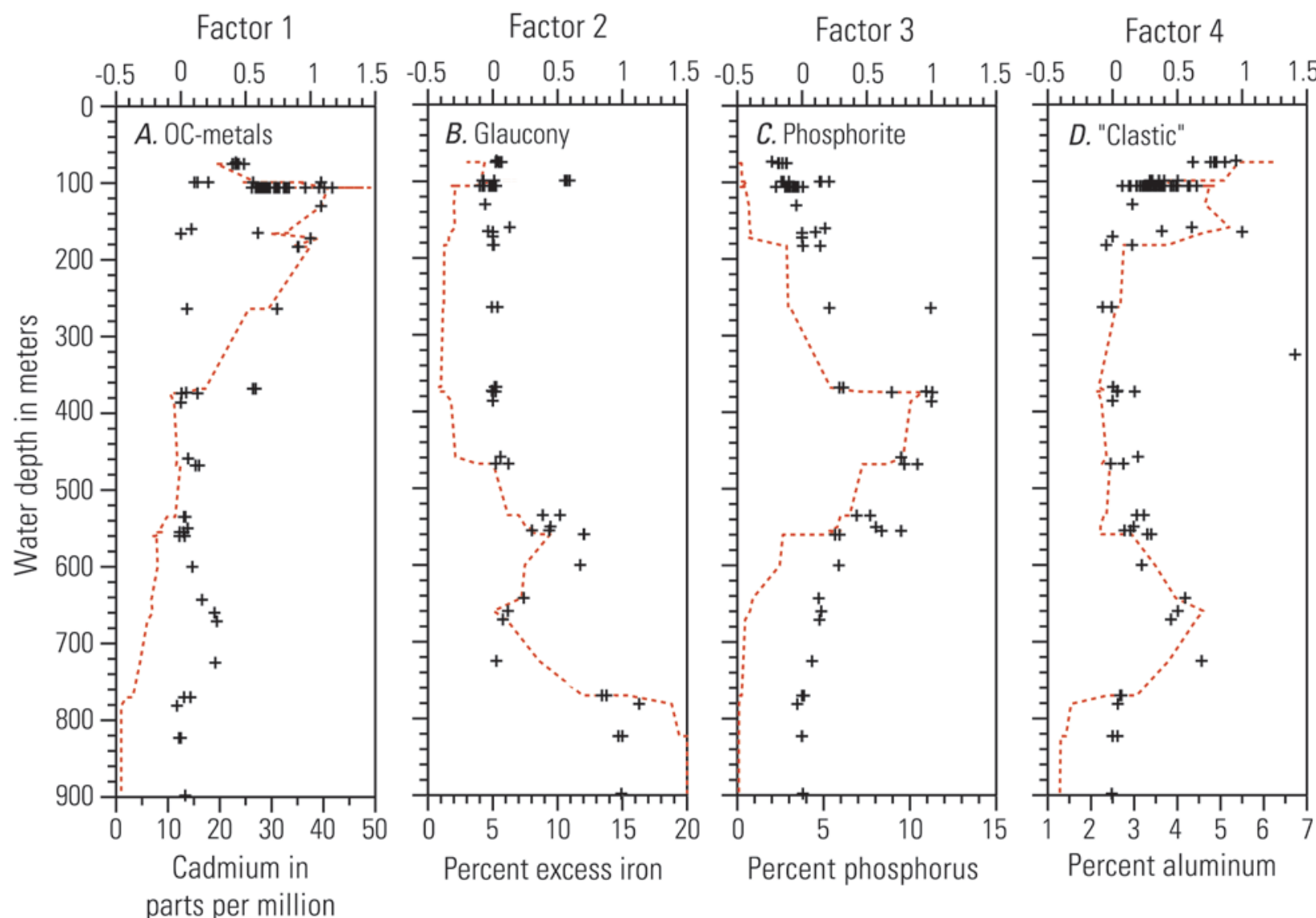

Figure 8. Plots of factor loadings versus water depth along the $13.5^{\circ} \mathrm{S}$ transect for $(A)$ factor 1 , organic carbon and metals, $(B)$ factor 2, glaucony, $(C)$ factor 3, phosphorite, and $(D)$ factor 4, clastic, from Qmode factor analysis of chemical composition of surface sediments. Dashed red lines are 5-point moving averages of the elemental data. (OC, organic carbon) 

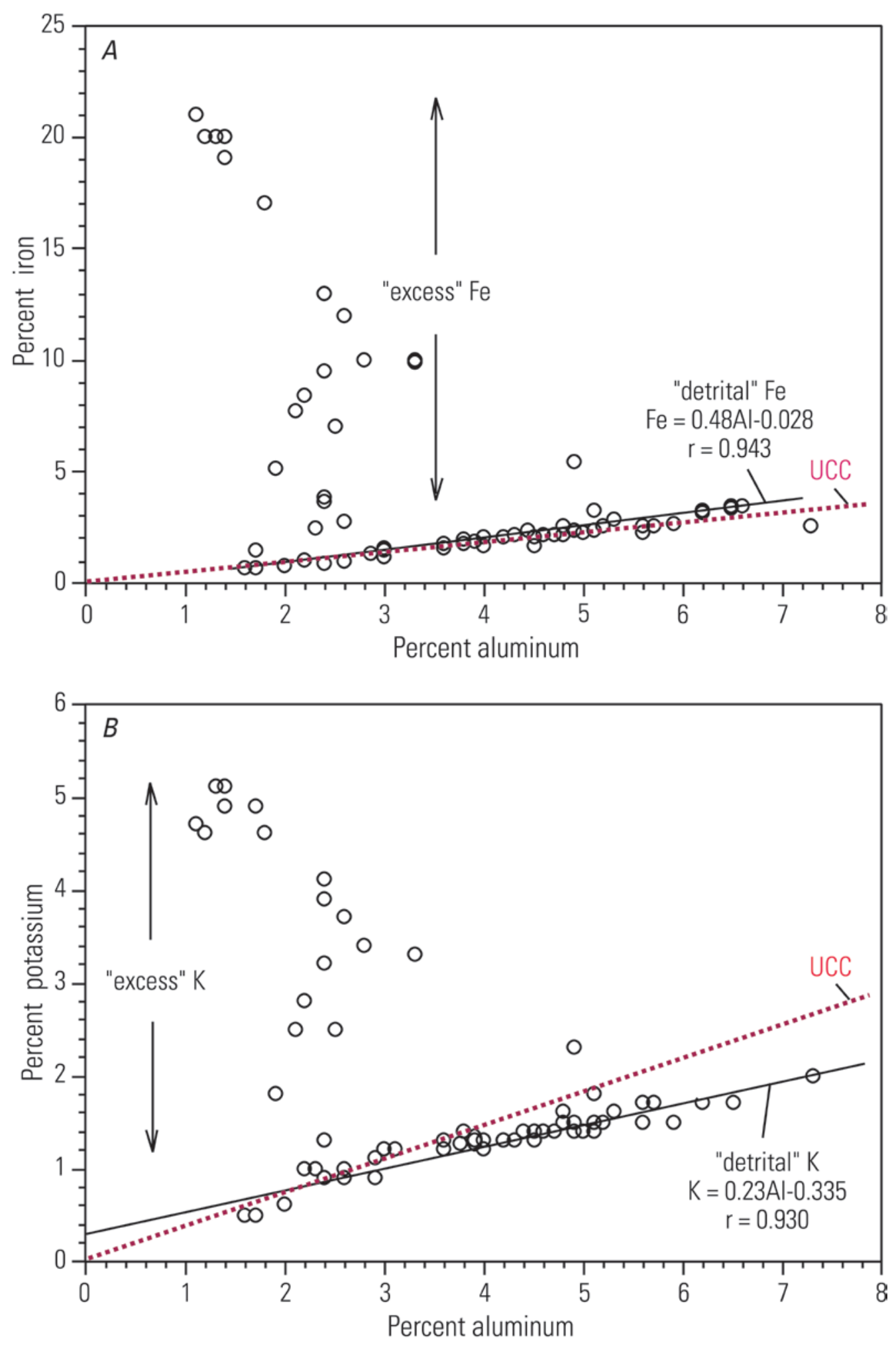

Figure 9. Plots of percent aluminum (Al) versus $(A)$ percent iron $(\mathrm{Fe})$ and $(B)$ percent potassium $(\mathrm{K})$ for all samples along the $13.5^{\circ} \mathrm{S}$ transect. See text for methods of calculations of detrital and excess concentrations. Red dashed lines are the regression lines for the composition of upper continental crust (UCC) (Wedepohl, 1995). 
Table 3. Composition of Q-mode factor analysis end-member samples and samples of glaucony pellets, phosphorite crusts and nodules, and dolomitic crusts collected along the $13.5^{\circ} \mathrm{S}$ transect on the Peru margin.

[ID, identification; F., factor; JSL, DS/V Johnson Sea-Link II; BC, box core; OC, organic carbon; IC, inorganic carbon; m, meter; \%, percent; ppm, parts per million]

\begin{tabular}{|c|c|c|c|c|c|c|c|c|c|c|c|c|c|c|c|c|}
\hline Sample ID & Latitude & Longitude & $\begin{array}{c}\text { Water } \\
\text { depth }(m)\end{array}$ & $\begin{array}{l}\mathrm{Si} \\
\%\end{array}$ & $\begin{array}{c}\mathrm{SiO}_{2} \\
\% \\
\end{array}$ & $\begin{array}{l}\mathrm{Al} \\
\%\end{array}$ & $\begin{array}{c}\mathrm{Al}_{2} \mathrm{O}_{3} \\
\%\end{array}$ & $\begin{array}{c}\mathrm{Fe} \\
\%\end{array}$ & $\begin{array}{c}\mathrm{Fe}_{2} \mathrm{O}_{3} \\
\%\end{array}$ & $\begin{array}{c}\mathrm{Mg} \\
\%\end{array}$ & $\begin{array}{c}\mathrm{MgO} \\
\%\end{array}$ & $\begin{array}{l}\mathrm{Ca} \\
\%\end{array}$ & $\begin{array}{c}\mathrm{CaO} \\
\% \\
\end{array}$ & $\begin{array}{c}\mathrm{Na} \\
\% \\
\end{array}$ & $\begin{array}{c}\mathrm{Na}_{2} \mathrm{O} \\
\%\end{array}$ & $\begin{array}{l}\mathrm{K} \\
\% \\
\end{array}$ \\
\hline \multicolumn{17}{|c|}{ End members } \\
\hline F. 1: JSL 3348-3 & $13^{\circ} 31.00^{\prime} \mathrm{S}$ & $76^{\circ} 43.06^{\prime} \mathrm{W}$ & 183 & 13 & 28 & 3.8 & 7.2 & 1.6 & 2.2 & 1.4 & 2.3 & 1.8 & 2.5 & 4.3 & 5.8 & 0.66 \\
\hline F. 2: JSL 3351-1 & $13^{\circ} 29.87^{\prime} \mathrm{S}$ & $77^{\circ} 02.07^{\prime} \mathrm{W}$ & 823 & 22 & 48 & 1.4 & 2.6 & 20 & 28 & 2.1 & 3.6 & 0.4 & 0.5 & 0.9 & 1.2 & 4.51 \\
\hline F. 3: JSL 3356-1 & $13^{\circ} 29.77^{\prime} \mathrm{S}$ & $76^{\circ} 51.98^{\prime} \mathrm{W}$ & 386 & 4.9 & 10 & 1.5 & 2.8 & 0.8 & 1.1 & 0.8 & 1.3 & 28 & 39 & 1.0 & 1.3 & 0.12 \\
\hline F. 4: JSL 3345-1 & $13^{\circ} 31.36^{\prime} \mathrm{S}$ & $76^{\circ} 19.67^{\prime} \mathrm{W}$ & 75 & 20 & 44 & 6.3 & 12 & 3.3 & 4.7 & 1.9 & 3.2 & 1.7 & 2.4 & 5.2 & 7.1 & 1.31 \\
\hline \multicolumn{17}{|c|}{ Glaucony pellets } \\
\hline $\mathrm{BC} 50$ & $13^{\circ} 30.00^{\prime} \mathrm{S}$ & $77^{\circ} 03.00^{\prime} \mathrm{W}$ & 898 & 22 & 48 & 1.2 & 2.3 & 20 & 28 & 2.2 & 3.6 & 0.4 & 0.5 & 0.9 & 1.2 & 4.27 \\
\hline $\mathrm{BC} 43$ & $13^{\circ} 30.65^{\prime} \mathrm{S}$ & $77^{\circ} 01.83^{\prime} \mathrm{W}$ & 781 & 23 & 48 & 1.3 & 2.5 & 20 & 29 & 2.2 & 3.6 & 0.3 & 0.4 & 0.4 & 0.6 & 5.40 \\
\hline \multicolumn{17}{|c|}{ Crusts and nodules } \\
\hline D-527999 & $13^{\circ} 39.79^{\prime} \mathrm{S}$ & $76^{\circ} 47.80^{\prime} \mathrm{W}$ & 256 & 6.4 & 14 & 1.6 & 2.9 & 1.2 & 1.8 & 0.6 & 1.0 & 28 & 39 & 1.2 & 1.7 & 0.55 \\
\hline D-528002 & $13^{\circ} 29.72^{\prime} \mathrm{S}$ & $76^{\circ} 47.89^{\prime} \mathrm{W}$ & 255 & 7.4 & 16 & 1.9 & 3.6 & 2.4 & 3.4 & 0.7 & 1.1 & 26 & 36 & 1.2 & 1.7 & 0.74 \\
\hline D-528003 & $13^{\circ} 29.55^{\prime} \mathrm{S}$ & $76^{\circ} 47.79^{\prime} \mathrm{W}$ & 255 & 7.7 & 17 & 2.0 & 3.9 & 1.4 & 2.0 & 0.8 & 1.3 & 25 & 35 & 1.2 & 1.6 & 0.61 \\
\hline D-528004 & $13^{\circ} 30.47^{\prime} \mathrm{S}$ & $76^{\circ} 55.42^{\prime} \mathrm{W}$ & 528 & 6.5 & 14 & 1.7 & 3.2 & 1.6 & 2.2 & 0.6 & 1.0 & 27 & 38 & 1.3 & 1.7 & 0.58 \\
\hline D-528006 & $13^{\circ} 30.72^{\prime} \mathrm{S}$ & $76^{\circ} 54.63^{\prime} \mathrm{W}$ & 488 & 5.5 & 12 & 1.3 & 2.4 & 2.3 & 3.3 & 0.7 & 1.1 & 28 & 39 & 1.2 & 1.6 & 0.66 \\
\hline D-528000 & $13^{\circ} 29.55^{\prime} \mathrm{S}$ & $76^{\circ} 47.79^{\prime} \mathrm{W}$ & 255 & 19 & 41 & 5.0 & 9.4 & 2.1 & 3.0 & 4.6 & 7.7 & 10 & 13 & 1.8 & 2.5 & 1.29 \\
\hline D-528001 & $13^{\circ} 29.55^{\prime} \mathrm{S}$ & $76^{\circ} 47.79^{\prime} \mathrm{W}$ & 255 & 12 & 27 & 3.3 & 6.3 & 2.3 & 3.2 & 4.7 & 7.8 & 16 & 22 & 1.5 & 2.0 & 0.85 \\
\hline D-528005 & $13^{\circ} 30.72^{\prime} \mathrm{S}$ & $76^{\circ} 54.63^{\prime} \mathrm{W}$ & 488 & 14 & 30 & 3.5 & 6.7 & 1.7 & 2.4 & 6.0 & 9.9 & 13 & 19 & 1.3 & 1.8 & 0.86 \\
\hline
\end{tabular}

\section{End members:}

Factor 1 end member (OC-metals) JSL Dive 3348, submersible push core 3 Factor 2 end member (glaucony) JSL Dive 3351, submersible push core 1

Factor 3 end member (phosphorite) JSL Dive 3356, submersible push core 1 Factor 4 end member (detrital) JSL Dive 3345, submersible push core 1

Glaucony: deck-deployed box cores 50 and 43

\section{Crusts and nodules:}

D-527999 mature phosphate nodule from JSL Dive 3350

D-528002 mature phosphate crust from JSL Dive 3352

D-528003 bioturbated phosphate crust from JSL Dive 3352

D-528004 bioturbated phosphate crust from JSL Dive 3354

D-528006

D-528000

D-528001 mature phosphate nodule from JSL Dive 3355

dolomitic crust from JSL Dive 3352

D-528005 
Table 3. Composition of Q-mode factor analysis end-member samples .-Continued

[ID, identification; F., factor; JSL, DS/V Johnson Sea-Link II; BC, box core; OC, organic carbon; IC, inorganic carbon; m, meter; \%, percent; ppm, parts per million]

\begin{tabular}{|c|c|c|c|c|c|c|c|c|c|c|c|c|c|c|c|}
\hline Sample ID & Latitude & Longitude & $\begin{array}{c}\text { Water } \\
\text { depth }(m)\end{array}$ & $\begin{array}{c}\mathrm{K}_{2} \mathrm{O} \\
\%\end{array}$ & $\begin{array}{l}\mathrm{Ti} \\
\%\end{array}$ & $\begin{array}{c}\mathrm{TiO}_{2} \\
\%\end{array}$ & $\begin{array}{l}\mathbf{P} \\
\%\end{array}$ & $\begin{array}{c}\mathrm{P}_{2} \mathrm{O}_{5} \\
\%\end{array}$ & $\begin{array}{c}\mathrm{Mn} \\
\mathrm{ppm}\end{array}$ & $\begin{array}{c}\mathrm{Mn0} \\
\%\end{array}$ & $\begin{array}{c}\text { As } \\
\mathrm{ppm}\end{array}$ & $\begin{array}{c}\mathrm{Ba} \\
\mathrm{ppm}\end{array}$ & $\begin{array}{c}\mathrm{Cd} \\
\mathrm{ppm}\end{array}$ & $\begin{array}{c}\mathrm{Ce} \\
\mathrm{ppm}\end{array}$ & $\begin{array}{l}\text { Co } \\
\text { ppm }\end{array}$ \\
\hline \multicolumn{16}{|c|}{ End members } \\
\hline F. 1: JSL 3348-3 & $13^{\circ} 31.00^{\prime} \mathrm{S}$ & $76^{\circ} 43.06^{\prime} \mathrm{W}$ & 183 & 0.79 & 0.17 & 0.28 & 0.34 & 0.78 & 160 & 0.020 & 15 & 260 & 54 & 21 & 8 \\
\hline F. 2: JSL 3351-1 & $13^{\circ} 29.87^{\prime} \mathrm{S}$ & $77^{\circ} 02.07^{\prime} \mathrm{W}$ & 823 & 5.43 & 0.05 & 0.08 & 0.07 & 0.17 & 13 & 0.002 & 11 & 37 & 1 & 3 & 4 \\
\hline F. 3: JSL 3356-1 & $13^{\circ} 29.77^{\prime} \mathrm{S}$ & $76^{\circ} 51.98^{\prime} \mathrm{W}$ & 386 & 0.14 & 0.07 & 0.12 & 12 & 28 & 71 & 0.009 & 10 & 98 & 5 & 13 & 7 \\
\hline F. 4: JSL 3345-1 & $13^{\circ} 31.36^{\prime} \mathrm{S}$ & $76^{\circ} 19.67^{\prime} \mathrm{W}$ & 75 & 1.58 & 0.31 & 0.51 & 0.11 & 0.25 & 460 & 0.060 & 19 & 350 & 18 & 36 & 20 \\
\hline \multicolumn{16}{|c|}{ Glaucony pellets } \\
\hline $\mathrm{BC} 50$ & $13^{\circ} 30.00^{\prime} \mathrm{S}$ & $77^{\circ} 03.00^{\prime} \mathrm{W}$ & 898 & 5.15 & 0.05 & 0.08 & 0.08 & 0.19 & 100 & 0.013 & 12 & 36 & 1 & 3 & 5 \\
\hline $\mathrm{BC} 43$ & $13^{\circ} 30.65^{\prime} \mathrm{S}$ & $77^{\circ} 01.83^{\prime} \mathrm{W}$ & 781 & 6.50 & 0.05 & 0.08 & 0.08 & 0.18 & 21 & 0.003 & 17 & 16 & 1 & 3 & 5 \\
\hline \multicolumn{16}{|c|}{ Crusts and nodules } \\
\hline D-527999 & $13^{\circ} 39.79^{\prime} \mathrm{S}$ & $76^{\circ} 47.80^{\prime} \mathrm{W}$ & 256 & 0.66 & 0.07 & 0.11 & 12 & 28 & 70 & 0.009 & 17 & 120 & 7 & 17 & 8 \\
\hline D-528002 & $13^{\circ} 29.72^{\prime} \mathrm{S}$ & $76^{\circ} 47.89^{\prime} \mathrm{W}$ & 255 & 0.89 & 0.10 & 0.17 & 11 & 25 & 130 & 0.017 & 32 & 120 & 5 & 12 & 8 \\
\hline D-528003 & $13^{\circ} 29.55^{\prime} \mathrm{S}$ & $76^{\circ} 47.79^{\prime} \mathrm{W}$ & 255 & 0.73 & 0.11 & 0.18 & 10 & 25 & 130 & 0.017 & 17 & 140 & 5 & 21 & 15 \\
\hline D-528004 & $13^{\circ} 30.47^{\prime} \mathrm{S}$ & $76^{\circ} 55.42^{\prime} \mathrm{W}$ & 528 & 0.70 & 0.10 & 0.16 & 11 & 25 & 110 & 0.014 & 29 & 120 & 6 & 19 & 39 \\
\hline D-528006 & $13^{\circ} 30.72^{\prime} \mathrm{S}$ & $76^{\circ} 54.63^{\prime} \mathrm{W}$ & 488 & 0.80 & 0.07 & 0.12 & 12 & 28 & 98 & 0.013 & 21 & 89 & 8 & 42 & 7 \\
\hline D-528000 & $13^{\circ} 29.55^{\prime} \mathrm{S}$ & $76^{\circ} 47.79^{\prime} \mathrm{W}$ & 255 & 1.55 & 0.25 & 0.41 & 0.25 & 0.58 & 350 & 0.045 & 27 & 360 & 1 & 29 & 12 \\
\hline D-528001 & $13^{\circ} 29.55^{\prime} \mathrm{S}$ & $76^{\circ} 47.79^{\prime} \mathrm{W}$ & 255 & 1.03 & 0.19 & 0.32 & 2.88 & 6.6 & 230 & 0.030 & 55 & 220 & 16 & 20 & 30 \\
\hline D-528005 & $13^{\circ} 30.72^{\prime} \mathrm{S}$ & $76^{\circ} 54.63^{\prime} \mathrm{W}$ & 488 & 1.04 & 0.17 & 0.28 & 0.81 & 1.9 & 190 & 0.025 & 17 & 260 & 1 & 26 & 43 \\
\hline
\end{tabular}

\section{End members:}

Factor 1 end member (OC-metals) JSL Dive 3348, submersible push core 3 Factor 2 end member (glaucony) JSL Dive 3351, submersible push core 1 Factor 3 end member (phosphorite) JSL Dive 3356, submersible push core 1 Factor 4 end member (detrital) JSL Dive 3345, submersible push core 1

Glaucony: deck-deployed box cores 50 and 43

\section{Crusts and nodules:}

D-527999 mature phosphate nodule from JSL Dive 3350

D-528002 mature phosphate crust from JSL Dive 3352

D-528003 bioturbated phosphate crust from JSL Dive 3352

D-528004 bioturbated phosphate crust from JSL Dive 3354

D-528006 mature phosphate nodule from JSL Dive 3355

D-528000

D-528001 dolomitic crust from JSL Dive 3352

dolomitic, phosphatic crust from JSL Dive 3352 dolomitic, phosphatic crust from JSL Dive 3355 
Table 3. Composition of Q-mode factor analysis end-member samples - Continued

[ID, identification; F., factor; JSL, DS/V Johnson Sea-Link II; BC, box core; OC, organic carbon; IC, inorganic carbon; m, meter; \%, percent; ppm, parts per million]

\begin{tabular}{|c|c|c|c|c|c|c|c|c|c|c|c|c|c|c|c|}
\hline Sample ID & Latitude & Longitude & $\begin{array}{c}\text { Water } \\
\text { depth }(m)\end{array}$ & $\begin{array}{c}\mathrm{Cr} \\
\mathrm{ppm}\end{array}$ & $\begin{array}{c}\mathrm{Cu} \\
\mathrm{ppm}\end{array}$ & $\begin{array}{c}\text { La } \\
\text { Ppm }\end{array}$ & $\begin{array}{c}\mathrm{Li} \\
\mathrm{ppm}\end{array}$ & $\begin{array}{c}\text { Mo } \\
\text { ppm }\end{array}$ & $\begin{array}{c}\mathrm{Ni} \\
\mathrm{ppm}\end{array}$ & $\begin{array}{c}\text { Sr } \\
\text { ppm }\end{array}$ & $\begin{array}{c}\mathrm{V} \\
\mathrm{ppm}\end{array}$ & $\begin{array}{c}\mathrm{Y} \\
\mathrm{ppm}\end{array}$ & $\begin{array}{c}\mathrm{Zn} \\
\mathrm{ppm}\end{array}$ & $\begin{array}{l}\text { IC } \\
\%\end{array}$ & $\begin{array}{c}\text { OC } \\
\%\end{array}$ \\
\hline \multicolumn{16}{|c|}{ End members } \\
\hline F. 1: JSL 3348-3 & $13^{\circ} 31.00^{\prime} \mathrm{S}$ & $76^{\circ} 43.06^{\prime} \mathrm{W}$ & 183 & 170 & 81 & 12 & 27 & 63 & 150 & 220 & 260 & 13 & 110 & 0.21 & 18 \\
\hline F. 2: JSL 3351-1 & $13^{\circ} 29.87^{\prime} \mathrm{S}$ & $77^{\circ} 02.07^{\prime} \mathrm{W}$ & 823 & 460 & 24 & 1 & 14 & 1 & 26 & 42 & 69 & 1 & 47 & 0.08 & 1.2 \\
\hline F. 3: JSL 3356-1 & $13^{\circ} 29.77^{\prime} \mathrm{S}$ & $76^{\circ} 51.98^{\prime} \mathrm{W}$ & 386 & 89 & 17 & 10 & 11 & 6 & 28 & 2,000 & 56 & 21 & 38 & 1.70 & 2.2 \\
\hline F. 4: JSL 3345-1 & $13^{\circ} 31.36^{\prime} \mathrm{S}$ & $76^{\circ} 19.67^{\prime} \mathrm{W}$ & 75 & 54 & 83 & 19 & 46 & 37 & 30 & 230 & 160 & 14 & 150 & 0.12 & 3.5 \\
\hline \multicolumn{16}{|c|}{ Glaucony pellets } \\
\hline BC50 & $13^{\circ} 30.00^{\prime} \mathrm{S}$ & $77^{\circ} 03.00^{\prime} \mathrm{W}$ & 898 & 480 & 30 & 2 & 16 & 1 & 30 & 43 & 66 & 1 & 59 & 0.06 & 1.1 \\
\hline $\mathrm{BC} 43$ & $13^{\circ} 30.65^{\prime} \mathrm{S}$ & $77^{\circ} 01.83^{\prime} \mathrm{W}$ & 781 & 510 & 23 & 2 & 15 & 1 & 27 & 34 & 79 & 3 & 42 & 0.05 & 1.0 \\
\hline \multicolumn{16}{|c|}{ Crusts and nodules } \\
\hline D-527999 & $13^{\circ} 39.79^{\prime} \mathrm{S}$ & $76^{\circ} 47.80^{\prime} \mathrm{W}$ & 256 & 130 & 35 & 12 & 6 & 3 & 27 & 2,100 & 50 & 19 & 31 & & \\
\hline D-528002 & $13^{\circ} 29.72^{\prime} \mathrm{S}$ & $76^{\circ} 47.89^{\prime} \mathrm{W}$ & 255 & 130 & 13 & 11 & 11 & 8 & 50 & 1,700 & 61 & 11 & 30 & & \\
\hline D-528003 & $13^{\circ} 29.55^{\prime} \mathrm{S}$ & $76^{\circ} 47.79^{\prime} \mathrm{W}$ & 255 & 110 & 20 & 18 & 12 & 1 & 25 & 2,000 & 48 & 27 & 45 & & \\
\hline D-528004 & $13^{\circ} 30.47^{\prime} \mathrm{S}$ & $76^{\circ} 55.42^{\prime} \mathrm{W}$ & 528 & 140 & 28 & 13 & 11 & 8 & 58 & 2,000 & 210 & 19 & 41 & & \\
\hline D-528006 & $13^{\circ} 30.72^{\prime} \mathrm{S}$ & $76^{\circ} 54.63^{\prime} \mathrm{W}$ & 488 & 150 & 16 & 12 & 9 & 5 & 46 & 2,000 & 80 & 17 & 34 & & \\
\hline D-528000 & $13^{\circ} 29.55^{\prime} \mathrm{S}$ & $76^{\circ} 47.79^{\prime} \mathrm{W}$ & 255 & 37 & 16 & 17 & 24 & 17 & 8 & 500 & 70 & 11 & 43 & & \\
\hline D-528001 & $13^{\circ} 29.55^{\prime} \mathrm{S}$ & $76^{\circ} 47.79^{\prime} \mathrm{W}$ & 255 & 72 & 17 & 12 & 21 & 16 & 37 & 870 & 120 & 9 & 44 & & \\
\hline D-528005 & $13^{\circ} 30.72^{\prime} \mathrm{S}$ & $76^{\circ} 54.63^{\prime} \mathrm{W}$ & 488 & 260 & 18 & 16 & 17 & 1 & 17 & 650 & 67 & 17 & 29 & & \\
\hline
\end{tabular}

\section{End members:}

Factor 1 end member (OC-metals) JSL Dive 3348, submersible push core 3

Factor 2 end member (glaucony) JSL Dive 3351, submersible push core 1

Factor 3 end member (phosphorite) JSL Dive 3356, submersible push core 1

Factor 4 end member (detrital) JSL Dive 3345, submersible push core 1

\section{Crusts and nodules:}

D-527999 mature phosphate nodule from JSL Dive 3350

D-528002 mature phosphate crust from JSL Dive 3352

D-528003 bioturbated phosphate crust from JSL Dive 3352

D-528004 bioturbated phosphate crust from JSL Dive 3354

D-528006 mature phosphate nodule from JSL Dive 3355

D-528000 dolomitic crust from JSL Dive 3352

D-528001 dolomitic, phosphatic crust from JSL Dive 3352

D-528005 dolomitic, phosphatic crust from JSL Dive 3355 
Factor 3 sediments on the $13.5^{\circ} \mathrm{S}$ transect are phosphatic, similar to those of factor 2 sediments on the $12^{\circ} \mathrm{S}$ transect with high concentrations of Ca, P, Sr, Y, and IC (tables 1 and 2). Yttrium and other rare-earth elements usually are enriched in CFA (Byrne and others, 1996). The phosphate-rich factor 3 sediments on the $13.5^{\circ} \mathrm{S}$ transect are found on the upper slope between 250 and $550 \mathrm{~m}$ (fig. 8C), which is slightly shallower than the phosphate-rich sediments that occur between 350 and $750 \mathrm{~m}$ on the $12^{\circ} \mathrm{S}$ transect (fig. $7 B$ ). Factor 3 accounted for 8.5 percent of the variance in the scaled data.

The relations between $\mathrm{Ca}, \mathrm{P}$, and $\mathrm{IC}$ for samples from both transects show that calcium resides in both CFA and calcite (mostly from benthic forminifera), and allow us to determine the concentrations of CFA and calcite independently. On the $12^{\circ} \mathrm{S}$ transect the linear Ca-P relationship $(\% \mathrm{P}=0.44 \% \mathrm{Ca}-1.2, \mathrm{r}=0.970$; fig. $10 A)$ is essentially the same as for the $13.5^{\circ} \mathrm{S}$ transect $(\% \mathrm{P}=0.48 \% \mathrm{Ca}-1.03, \mathrm{r}=0.994$; fig. $10 \mathrm{~B})$. Samples of phosphorite crusts collected by submersible from both transects contain about $28 \% \mathrm{Ca}$ and $12 \% \mathrm{P}(\mathrm{P} / \mathrm{Ca}=0.43$; for example, sample D-527999), identical to the concentrations in the factor 3 end-member sample (table 3 ). The $\mathrm{P} / \mathrm{Ca}$ ratio of 0.43 is close to the $\mathrm{P} / \mathrm{Ca}$ slope ratios from the two regression equations $(0.44$ and 0.48 , fig. 10). Using a $\mathrm{P} / \mathrm{Ca}$ ratio of 0.43 , and assuming that all of the $\mathrm{P}$ was in $\mathrm{CFA}$, we calculated percent CFA-Ca for each sample as percent total-P divided by 0.43 . We then calculated the percentage of calcite-Ca in each sample by subtracting percent CFA-Ca from percent total-Ca. Finally, percent $\mathrm{CaCO}_{3}$-calcite (shown in fig. 6) was calculated by dividing calcite-Ca by 0.4 , the fraction of $\mathrm{Ca}$ in $\mathrm{CaCO}_{3}$. Using these relations, an end-member phosphorite contains $12 \% \mathrm{P}$ (table 3; fig. 10), and the amount of phosphorite in any sample can be calculated. The average amount of phosphorite in all samples on the $12^{\circ} \mathrm{S}$ transect is 25 percent (range $1-100$ percent), and in all samples on the $13.5^{\circ} \mathrm{S}$ transect is 15 percent (range $1-$ 100 percent).

Factor 4 sediments on the $13.5^{\circ} \mathrm{S}$ transect, like factor 3 sediments on the $12^{\circ} \mathrm{S}$ transect, are composed mainly of detrital clastic material only weakly diluted by CFA, glaucony, or organic matter. Elements that were used to group factor 4 sediments are Ti, Th, Al, Ce, Li, Mn, $\mathrm{Ga}, \mathrm{Nd}, \mathrm{Sc}, \mathrm{Ba}, \mathrm{Nb}, \mathrm{Zn}, \mathrm{La}, \mathrm{Co}$, and $\mathrm{Cu}$ in order of decreasing correlation coefficients with factor 4 loadings (table 2). Sediments with highest loadings for factor 4 occur on the inner shelf at about $100 \mathrm{~m}$ (fig. 8D), largely in association with OC-rich factor 1 sediments. Factor 4 only accounts for 3.4 percent of the variance in the scaled data.

One other consideration is an estimate of the contribution of biogenic Si (opal) to Peru margin sediments. We have data for \% Si by XRF for most of the surface-sediment samples from the $13.5^{\circ} \mathrm{S}$ transect that allow us to estimate the biogenic Si concentration using the following methodology. First, the detrital (aluminosilicate) Si concentration was calculated assuming that the $\mathrm{Si} / \mathrm{Al}$ in the detrital fraction on the Peru margin was the same as that in average continental crust (3.57; Wedepohl, 1995). Therefore, \% detrital Si =3.57Al (fig. 11A). "Excess" Si was then calculated by subtracting \% detrital Si from \% total Si (fig. 11B). Excess Si consists of Si from glaucony in sediments from water depths deeper than $400 \mathrm{~m}$ and from biosiliceous (diatom) debris in sediments from shallower depths. Sediments from water depths shallower than $400 \mathrm{~m}$ contain no glaucony, so the excess Si for these samples is predominantly biogenic Si. Highest glaucony Si values occur in samples from depths deeper than $400 \mathrm{~m}$, reaching a maximum for samples from depths deeper than $750 \mathrm{~m}$ (fig. 11B). 

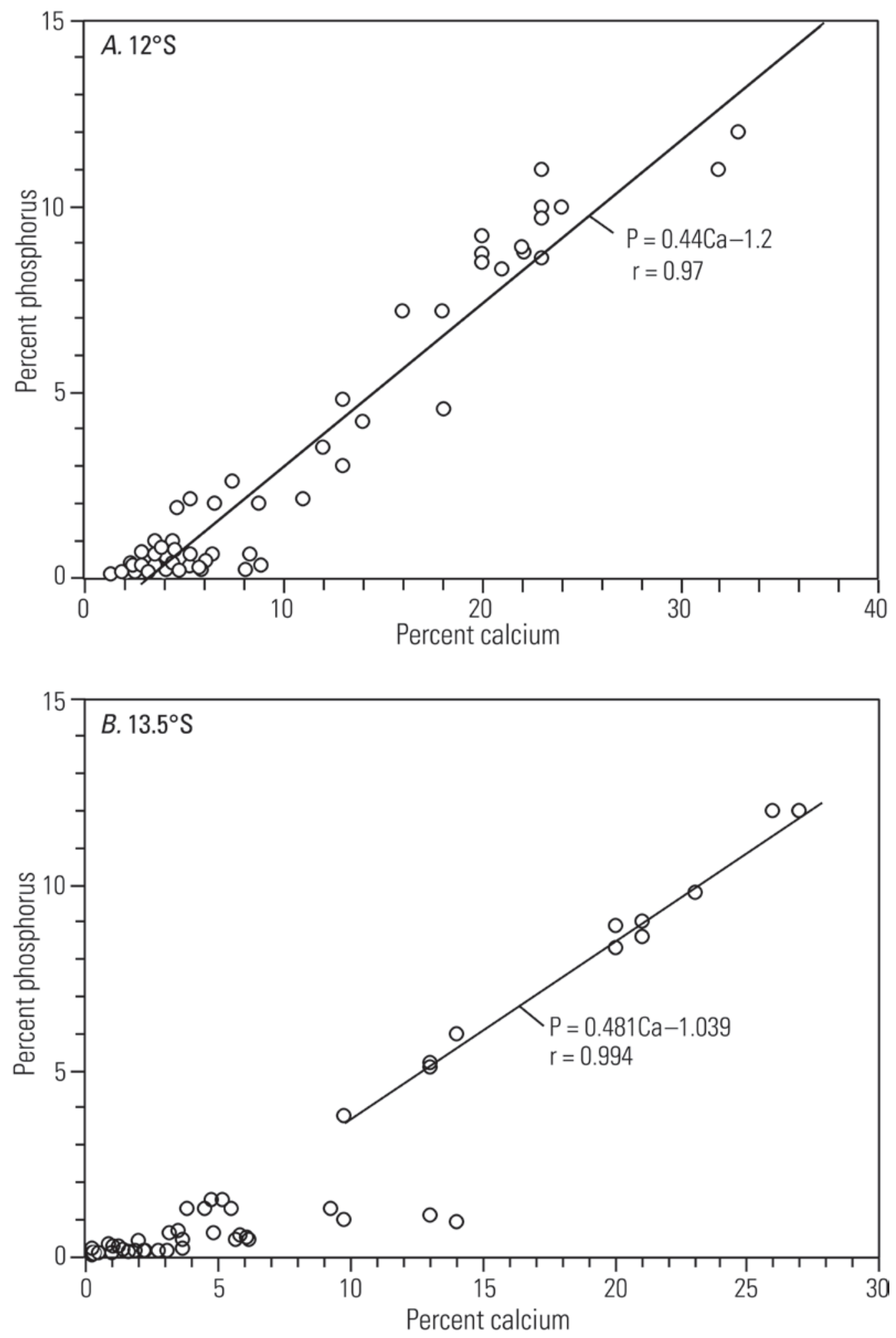

Figure 10. Plots of percent total calcium $(\mathrm{Ca})$ versus percent total phosphorus $(\mathrm{P})$ for all samples along $(A)$ the $12^{\circ} \mathrm{S}$ transect and $(B)$ the $13.5^{\circ} \mathrm{S}$ transect. Regression equations were calculated for samples with $>2$ percent total phosphorus. 

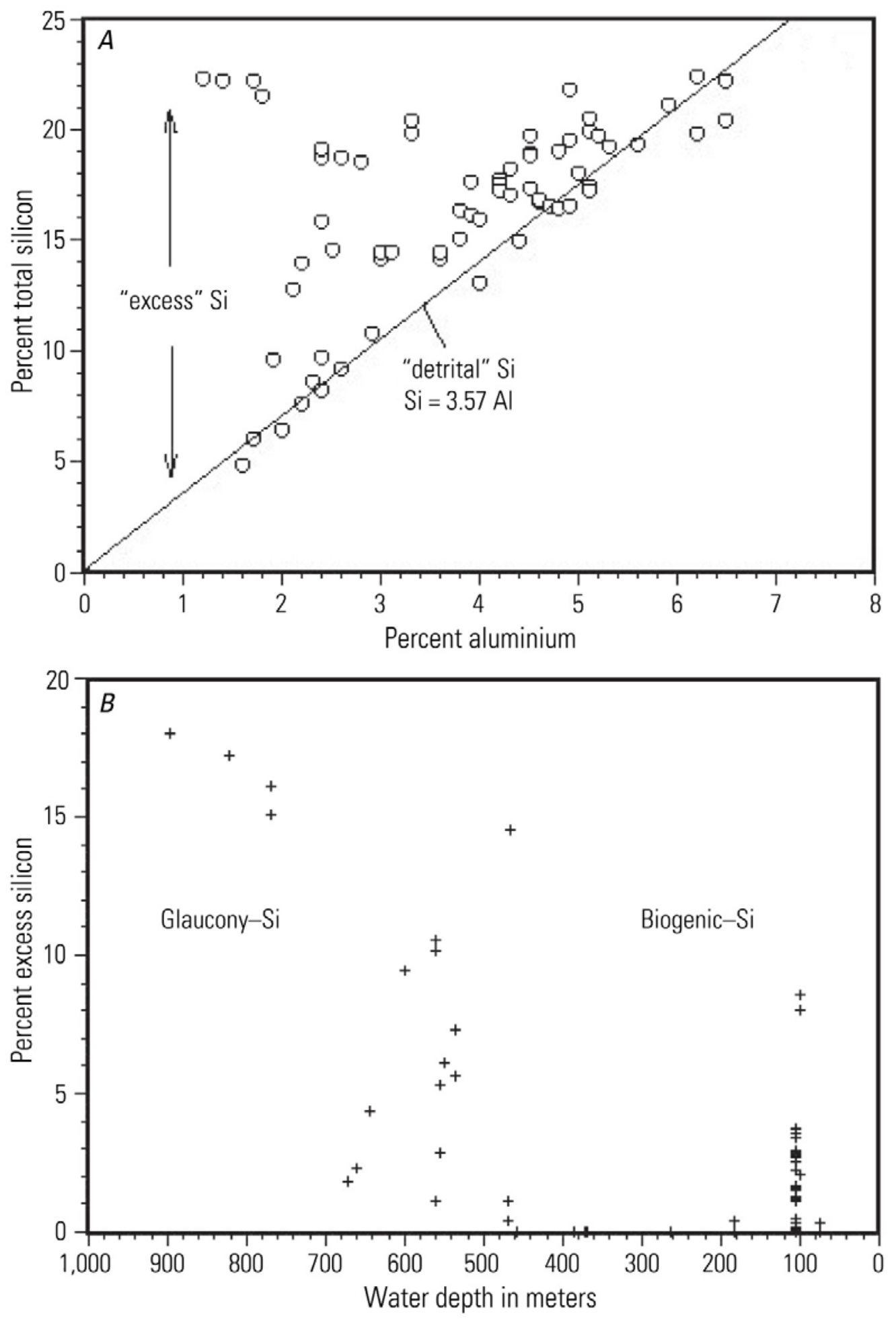

Figure 11. Plot of $(A)$ percent aluminum (Al) versus percent total silicon (Si) and $(B)$ water depth versus calculated percent excess Si for the $13.5^{\circ} \mathrm{S}$ transect. See text for methods of calculations of detrital and excess Si concentrations. In sediments at depths shallower than about 400 meters, most of the excess $\mathrm{Si}$ is in biogenic debris (diatoms), and in sediments at depths deeper than 400 meters, most of the excess $\mathrm{Si}$ is in glaucony. 


\section{Discussion}

\section{Geochemical Indicators of Bioproductivity}

\section{Organic Carbon Concentration and Preservation}

The source of organic matter to the seafloor on the Peru margin is almost entirely marine material that results from high primary productivity $(>200-400$ gram $C$ per square meter per year $\left[\mathrm{gC} / \mathrm{m}^{2} / \mathrm{yr}\right]$; Suess and others, 1987) associated with the Peru Current upwelling system. The dominant marine source is confirmed for sediment samples analyzed in this study by isotopic values of $\mathrm{OC}\left(\delta^{13} \mathrm{C}\right)$ ranging from -20 to $-21.5 \mathrm{ppm}$ relative to the Vienna Pee Dee Belemnite marine carbonate standard (VPDB) and by Rock-Eval pyrolysis (Arthur and others, 1998).

The hydrogen index (HI, in milligrams hydrocarbons per gram $\mathrm{OC}[\mathrm{mgHC} / \mathrm{gOC}]$ ) determined by the Rock-Eval pyrolysis technique is a rapid screening tool for the determination of the hydrocarbon source-rock potential of sedimentary rocks (Tissot and Welte, 1984; Peters, 1986). Pyrolysis can also be used to determine the hydrogen richness of protokerogen in modern sediments (for example, Liebezeit and Wiesner, 1990; Calvert and others, 1992; Pedersen and others, 1992; Arthur and others, 1994; Dean and Gardner, 1998; Ganeshram and others, 1999).

In sedimentary rocks, low values of $\mathrm{HI}(<100)$ usually indicate the presence of either highly oxidized organic matter of planktic origin or primarily terrestrially derived higher plant material (Peters, 1986). Consistently high HI values of $>400$ are found mainly in rocks that were deposited in environments interpreted to have been anoxic (for example, presence of fine laminations) and where there is no significant reworked material (for example, Pratt, 1984). Values of HI in sediments from both transects are mostly between 200 and 400 (fig. $6 B$ and $E$ ). Mixing of terrestrial organic matter $(\mathrm{HI}$ of $<100)$ and well-preserved algal organic matter (HI of $>400$ ) in various proportions is unlikely for the Peru margin samples given the low influx of detrital material. Also, there is no correlation between values of $\mathrm{HI}$ and values of $\delta^{13} \mathrm{C}$ (Arthur and others, 1998). Therefore, variations in values of $\mathrm{HI}$ in Peru margin surface sediments is likely due to variations in the degree of degradation of marine organic matter, particularly for the low-OC, low-HI samples below a water depth of $750 \mathrm{~m}$ on the $13.5^{\circ} \mathrm{S}$ transect (fig. $6 E$ ).

Concentrations of DO were $<5 \mu \mathrm{M}$ in water depths to $500 \mathrm{~m}$, and no macrobenthic organisms were observed between depths of 120 and $350 \mathrm{~m}$ (Arthur and others, 1994). Despite the low DO concentrations and absence of infaunal organisms, most cores did not contain fine laminations. Sediment transport and reworking by strong bottom currents must exert a major control on OC preservation on the Peru margin, as previously suggested by Suess and others (1987). We measured currents as high as $30 \mathrm{~cm} / \mathrm{s}$ at depths between 175 and $300 \mathrm{~m}$ within the core of the OMZ on both transects (fig. 3). The strongest southward-flowing (poleward) current is the Peru Undercurrent (Brockmann and others, 1980) that has a well-defined core at depths of $50-300 \mathrm{~m}$. The mean poleward velocity of the Peru Undercurrent at $10^{\circ} \mathrm{S}$ is $10 \mathrm{~cm} / \mathrm{s}$, but it commonly attains sustained velocities of $>25 \mathrm{~cm} / \mathrm{s}$ over periods of 2 days to 2 weeks (Brockmann and others, 1980). Therefore, on much of the Peru upper slope, constant advection of DO in low concentrations by bottom waters, resuspension of surficial organic matter, activity of organisms, and transport to and from more oxygenated zones contributes to greater oxidation and poorer preservation of organic matter than might be expected in a strong OMZ. This upper slope region also is characterized by fields of megaripples stabilized by bacterial mats, which is further evidence of a constant current flow. 


\section{Phosphorus Distribution and Phosphorite Formation}

As we discussed above, the sediments on the Peru margin are rich in phosphate, but most of that phosphate presently resides in CFA, either as unconsolidated sediments or in phosphorite nodules and crusts. Extensive pore-water and solid-phase studies of the upper $20-40 \mathrm{~cm}$ of box cores from the Peru shelf by Froelich and others (1988) demonstrate that CFA is precipitating today in the upper few centimeters of organic-rich, gelatinous sediments.

One of the most surprising results of submersible observations and coring on the Peru margin was that soft sediment is currently being cemented by CFA on the upper slope within the OMZ (protocrusts). Previous investigations concluded that nucleation of CFA occurred on preexisting hard substrates or by growth of phosphorite nodules and pellets within sediments (Glenn and Arthur, 1988). However, this precipitation must have occurred at or just below the sedimentwater interface based on the young ages (a few thousand years) of the various CFA morphotypes (Burnett and Veeh, 1977; Burnett and others, 1980, 1982, 1983, and 1988; Kim and Burnett, 1986, 1988). Although phosphorite pellets were abundant in muds recovered on a previous expedition to the same area (1982 R/V Robert Conrad; Baker and Burnett, 1988; Burnett and others, 1988), the widespread occurrences of phosphorite nodules, crusts, pavements, and phosphatic biogenic material (for example, whale bones) are the most prominent features observed on the $1992 R / V$ Seward Johnson expedition.

Our investigations of the authigenic crusts show that the crusts start by early diagenetic cementation of soft surface sediment (protocrusts) in water depths of 200-700 m, with the highest concentrations of CFA occurring between 400 and $500 \mathrm{~m}$ on the $12^{\circ} \mathrm{S}$ transect (fig. $7 \mathrm{~B}$ ), and between 300 and $60 \mathrm{~m}$ on the $13.5^{\circ} \mathrm{S}$ transect (fig. $8 \mathrm{C}$ ). The surficial origin of these crusts is supported by Burnett and others (2000), who found that CFA cementation of 1- to 3-cm-thick layers was initiated in the upper few centimeters of sediments in box cores. They concluded from radionuclide and carbon-isotope analyses that the CFA layers grew upwards towards the sediment-water interface. Their study suggests that precipitation of CFA occurs near the sediment-water interface and that the protocrusts grow upward over thousands of years.

Froelich and others (1988), who studied samples from the same area collected on the $1982 R / V$ Robert Conrad cruise, suggested that formation of CFA may be at least a two-step process that takes place near the sediment-water interface, first by precipitation of amorphous calcium phosphate then by addition of carbonate and fluorine in porewaters to form CFA. Rapid decreases in dissolved phosphate just below high values near the sediment-water interface suggested to them that phosphogenesis is currently occurring on the Peru margin at or just below the sediment-water interface. Froelich and others (1988) concluded that the phosphate flux that they observed across the sediment-water interface on the Peru margin was too great to be supported by decomposition of diatoms alone. Like Suess (1981) and deVries and Pearcy (1982), they concluded that fish debris (hydroxyapatite, HAP) is a significant biogenic source of phosphorous for phosphogenesis. Some HAP is converted directly to CFA, but most dissolves before it reaches the seafloor (Froelich and others, 1982). Another important source of phosphate and iron might be the "iron-redox pump" of Froelich and others $(1979,1988)$, which is discussed further below. Schuffert and others (1998), in their study of a different phosphogenic locality, called on fish debris as a source of $P$, but they favored an iron-redox pump as the primary source of P. The predominantly young age (Plio-Pleistocene) of the phosphorites recovered on the Peru margin during Ocean Drilling Program (ODP) Leg 112 led Garrison and Kastner (1990) to conclude that major phosphogenesis during the last two million years on the Peru margin occurred in response to intensified oceanic circulation that accompanied Pleistocene glaciation. 
They also suggested that the main source of phosphorus was from fish debris and not decomposition of organic matter.

\section{Geochemical Indicators of Redox Conditions}

\section{Organics and Metals}

The Q-mode factor analyses showed that the detrital clastic component on the Peru margin is a major component but is commonly diluted by organic matter and authigenic components. The detrital fraction can be estimated by the Al concentration of the sediments because $\mathrm{Al}$ is contributed entirely from that fraction. The average concentration of $\mathrm{Al}$ in surface sediments is 3.5 percent on the $12^{\circ} \mathrm{S}$ transect and 3.7 percent on the $13.5^{\circ} \mathrm{S}$ transect. The Al concentration in average upper continental crust is 7.7 percent (Wedepohl, 1995). Assuming that all of the Al in Peru margin sediments is in detrital clastic debris with an average composition close to that of upper continental crust, then the average contribution of detrital clastic debris is slightly $<50$ percent on both transects. The detrital contributions of other elements can be estimated by assuming that the element-to-aluminum ratio in detrital clastic debris in Peru margin sediments is the same as in average upper continental crust. The difference between the total concentration and the detrital concentrations for any element is the excess concentration that must be assigned to a hydrothermal or seawater source (Piper, 1994). Because there is no evidence for hydrothermal activity on the Peru margin, we assume that the excess amount of any element must have a seawater source, either in biogenic debris or in a precipitated endogenic or authigenic phase. The detrital and excess concentrations of $\mathrm{Cd}, \mathrm{Mo}, \mathrm{Cu}, \mathrm{Zn}, \mathrm{Ni}$, and $\mathrm{V}$ (the metals with highest correlations with the organic-metals factor loadings in tables 1 and 2) are given in table 4 .

Table 4. Detrital and excess concentrations of selected trace elements in surface sediments. [ppm, parts per million; \% Al, percent aluminum]

\begin{tabular}{|c|c|c|c|c|c|c|c|c|}
\hline \multirow[t]{2}{*}{ Element } & \multirow{2}{*}{$\begin{array}{l}\text { Upper } \\
\text { crust1 } \\
\text { (ppm) }\end{array}$} & \multirow{2}{*}{$\begin{array}{l}\text { Ratio to } \\
\% \mathrm{Al} \\
\text { in crust } \\
(\mathrm{ppm})\end{array}$} & \multicolumn{3}{|c|}{$12^{\circ} \mathrm{S}$ transect } & \multicolumn{3}{|c|}{$13.5^{\circ} \mathrm{S}$ transect } \\
\hline & & & $\begin{array}{l}\text { Total } \\
\text { (ppm) }\end{array}$ & $\begin{array}{l}\text { Detrital } \\
\text { (ppm) }\end{array}$ & $\begin{array}{c}\text { Excess } \\
\text { (ppm) }\end{array}$ & $\begin{array}{l}\text { Total } \\
\text { (ppm) }\end{array}$ & $\begin{array}{c}\text { Detrital } \\
\text { (ppm) }\end{array}$ & $\begin{array}{c}\text { Excess } \\
(\mathrm{ppm})\end{array}$ \\
\hline Cadmium & 0.10 & 0.013 & 26.2 & 0.05 & 26.2 & 25.3 & 0.05 & 25.2 \\
\hline Copper & 14 & 1.82 & 41.8 & 6.3 & 35.4 & 50.7 & 6.8 & 43.9 \\
\hline Zinc & 52 & 6.75 & 80 & 23 & 57 & 91 & 25 & 66 \\
\hline Nickel & 19 & 2.47 & 61.2 & 8.6 & 52.7 & 61.4 & 9.2 & 52.2 \\
\hline Vanadium & 53 & 6.88 & 133 & 24 & 109 & 150 & 26 & 124 \\
\hline Molybdenum & 1.4 & 0.18 & 31.6 & 0.6 & 31.0 & 42.4 & 0.7 & 41.7 \\
\hline Aluminum & 77,000 & & 35,000 & & & 37,000 & & \\
\hline
\end{tabular}

${ }^{1}$ Wedepohl, 1995.

It is clear from table 4 that a seawater (excess) source is required for all six trace elements; only Zn and V have significant detrital contributions. Because of high rain rates of biogenic debris on continental margins under upwelling regimes, these areas represent major sinks for many trace elements in the oceans today (for example, Collier and Edmond, 1984). This should be particularly true of the Peru margin because of the unusually high rate of primary productivity. However, because of large fluctuations in redox and sulfate-reducing conditions often occurring in the water as well as in the sediments, precipitation of redox-sensitive elements should also be expected. 
In Cariaco Basin sediments, 96.7 percent of Mo and 31.8 percent of V were derived from bottom water and (or) sediment pore water by adsorption and precipitation reactions (Piper and Dean, 2002). It is not possible to determine if this precipitation occurred in the water column (endogenic) or within the sediments (authigenic), but molecular diffusion of these elements from bottom waters into the sediments and precipitation at the sediment-water interface is most likely (Crusius and others, 1996; Helz and others, 1996). Most of the nondetrital (excess) metal concentrations in Peru margin sediments likely came from marine plankton. Some additions, particularly of Mo and V, may have resulted by sulfide precipitation in sulfidic bottom and (or) pore waters.

\section{Origin of Glaucony Pellets}

Sediments recovered from water depths $>750 \mathrm{~m}$ (to at least $1,067 \mathrm{~m}$ ) consist almost entirely of dark green glaucony pellets. A size analysis of one typical sample of the glaucony pellets from a water depth of $781 \mathrm{~m}$ (BC43; table 3) showed that the median grain size is $0.5-1.0$ millimeters (mm) (range of 63 micrometers $[\mu \mathrm{m}]$ to $2 \mathrm{~mm}$ ). Most of the minor finer-grained material consists of quartz and feldspar as determined by X-ray diffraction; minor sand-sized dolomite and CFA also are present. Most pellets are ellipsoidal in outline with surfaces covered with networks of septarian cracks filled with a tan material. The term pellet is used here to describe the shape of the grains with no particular implication as to origin. When the pellets are crushed, the platy habit of the clay minerals that make up the pellets is apparent.

According to Odin and Letolle (1980), glaucony can form in place from any mineral "framework" where the requisite ions $(\mathrm{Si}, \mathrm{Fe}, \mathrm{K}$, and $\mathrm{Mg}$ ) are "assembled;" it is not necessary to start with a related clay mineral (for example, iron smectite). The end product is an aggregate of clay minerals with a pelletoid shape. Because $\mathrm{K}$ and $\mathrm{Mg}$ are most likely derived from seawater to alter the original mineral framework, it is necessary for that framework to remain near the sediment-water interface in contact with seawater for a considerable time or glaucony will not form (Nishimura, 1994). On the other hand, Si and Fe can be supplied by dissolution of diatom opal and by Fe reduction in sediments beneath the site of formation. Therefore, the sedimentation rate in glaucony-forming environments must be extremely slow and there can be little diluting clastic material and relatively little agitation. According to Odin (1988), cracked, green pellets with a $\mathrm{K}_{2} \mathrm{O}$ content of approximately 6 percent (such as the pellets we collected on the Peru margin; table 3 ) require on the order of $10^{4}$ years to form; more mature pellets with $\mathrm{K}_{2} \mathrm{O}$ contents of $>8$ percent require even more time $\left(10^{5}\right.$ to $10^{6}$ years $)$.

The close association of glaucony with phosphorite (Odin and Letolle, 1980) suggests that the environment must have had a delicate balance between slightly oxidizing conditions for glaucony formation and slightly reducing conditions in order to mobilize iron and phosphate. Of the four areas that were investigated by Glenn and Arthur (1988) on the Peru margin between $8^{\circ} \mathrm{S}$ and $15^{\circ} \mathrm{S}$, glaucony grains were most abundant in sediments from the most oxidized area at about $8^{\circ} \mathrm{S}$. There, the glaucony grains were randomly disseminated in CFA cements that filled burrows. This intimate association of CFA with glaucony grains also was reported by Burnett (1980). Glenn and Arthur (1988) also observed that pyrite commonly fills fractures in and replaces parts of glaucony grains. They suggested that glauconitization occurred first, followed by phosphatization, and then replacement by pyrite.

Pore-water profiles measured by Froelich and others (1988) from the same areas of the Peru margin investigated by Glenn and Arthur (1988) suggest that the upper $10 \mathrm{~cm}$ of sediment is a zone of mixed suboxic to anoxic diagenesis. They proposed the "iron-redox pump" to 
explain the close association of glaucony and phosphorite under varying redox conditions. According to this mechanism, ferric oxyhydroxide from detrital clastic material is reduced at or just below the sediment-water interface releasing dissolved iron and adsorbed phosphate. Under conditions of sulfate reduction, some of the dissolved iron forms pyrite. Under slightly oxidizing conditions, dissolved iron, together with $\mathrm{Si}, \mathrm{K}$, and $\mathrm{Mg}$, alters a pre-existing carbonate and (or) detrital-clastic framework mineral to form glaucony. Froelich and others (1988) observed that the concentration of dissolved iron was below detection in the bottom water, was at a maximum at the sediment-water interface, decreased rapidly with depth below the sediment-water interface, and was below detection by the first traces of hydrogen sulfide. Some dissolved iron escapes above the sediment-water interface where it is oxidized to form iron oxyhydroxides with adsorbed phosphate providing more material for the iron-redox pump (Froelich and others, 1979).

The iron-redox pump scenario might explain the apparent occurrence of a small proportion $(<10$ percent) of glaucony detected by factor analysis in relatively OC-rich muds at depths of about $100 \mathrm{~m}$ (fig. $8 \mathrm{~B}$ ). However, the relative purity of glaucony on the Peru slope and the fact that the glaucony band is geographically distinct from the main phosphorite band suggest that a strong iron-redox pump did not exist. Suits and Arthur (2000) studied sulfur cycling in this area of the Peru margin using cores obtained on the $1992 \mathrm{R} / \mathrm{V}$ Seward Johnson expedition and concluded that glaucony probably could not form in OC-rich muds on the outer shelf or upper slope because the onset of bacterial sulfate reduction was very near the sediment-water interface, effectively precipitating all reactive iron as pyrite. Suits and Arthur (2000) concluded that iron would be available for glaucony formation only near the base of the OMZ where OC fluxes are low and sulfate-reduction in near-surface pore waters does not occur.

\section{Geochemical Indicators of Current Effects}

\section{Phosphorite}

The formation of thick and extensive phosphorite crusts requires that bottom currents periodically sweep the seafloor clean of fine-grained detritus above nascent protocrusts. Such currents were observed from and measured on the submersible (fig. 3). This winnowing and reworking produces lag deposits and the potential for numerous unconformities. From the submersible, we frequently observed surface lag deposits composed mainly of benthic foraminifera. However, growth of phosphorite crusts requires a continuous or at least intermittent source of dissolved phosphate (Froelich and others, 1988; Schuffert and others, 1998). Our study of crusts suggests that phosphorite crusts begin as layers of sediment up to several centimeters thick just below the sediment-water interface that are weakly cemented by CFA, and less commonly by dolomite; we have called these weakly cemented layers protocrusts (fig. $4 \mathrm{~A}$; fig. 12 , Stage 2). The early-formed protocrusts that we observed are only 0.5 - to 1.0 -cm thick but are sufficiently cohesive to crop out on the seafloor when undercut by the southward-flowing Peru undercurrent. We observed several areas where fragments of protocrust up to several centimeters in diameter have broken off of the eroded edge of protocrust outcrops, and covered the sediment on the adjacent seafloor. These protocrust fragments are further cemented by CFA to produce observed phosphorite breccias and (or) grow into phosphorite nodules. Nodules eventually coalesce to form phosphorite crusts and more extensive pavements (figs. $4 B$ and $C$; fig. 12 , stages 3 and 4). 


\section{Peru margin phosphate crust model}
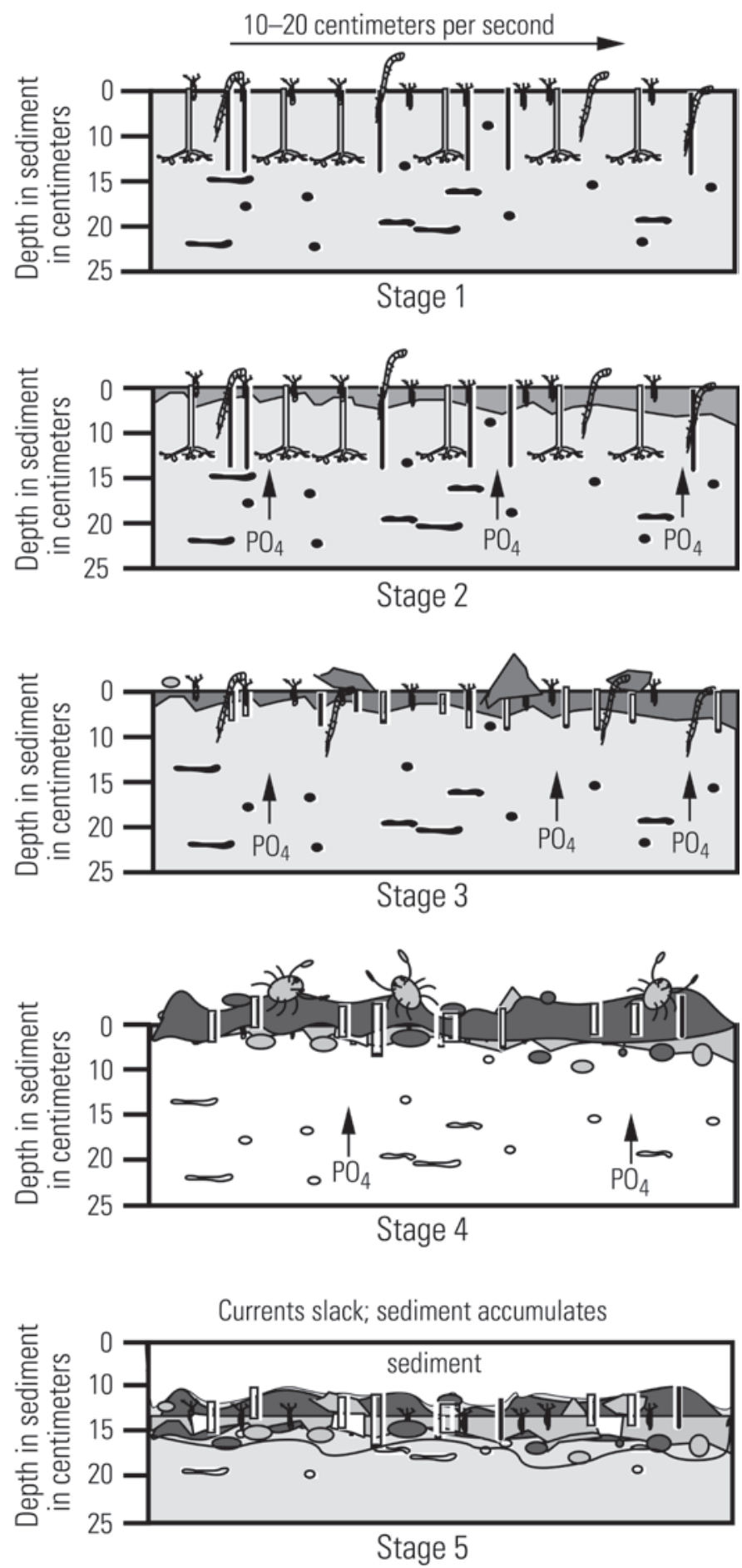

Figure 12. Hypothetical sequence of phosphorite crust formation on the Peru margin. Arrow with current velocity indicates active currents sweeping bottom in all but Stage 5. Otherwise, arrows indicate direction of diffusion of phosphate $\left(\mathrm{PO}_{4}\right)$ in the sediments. Stage 1 represents the initial condition of uncemented sediment. In Stage 2, the darker shading at the sediment surface illustrates the formation of a layer of friable, weakly cemented sediment (protocrust). In Stages 1 and 2 , vertical branching burrows of polychaete worms occur at the sediment-water interface. Dark shading in Stage 3 indicates a hardened phosphorite crust (D-type phosphorite of Garrison and Kastner, 1990). The protocrust is broken up by organisms then, in Stage 4, is exposed, cemented, and encrusted by epibionts and broken by large crabs. Burial of mature, multiple-generation D-type crust occurs in Stage 5 as currents slacken and sediment accumulates on top (lighter shading). 
Bottom currents keep the friable protocrusts exposed on the seafloor. With time, the protocrusts become more strongly cemented, but throughout cementation, the protocrusts and well-cemented crusts retain abundant holes formed in the original soft sediment by burrowing polychaete worms (figs. $4 A$ and $B$; fig. 12, Stage 3). Eventually, even the polychaete burrows become filled with cement, and the resulting phosphorite crust occurs in the form of hard nodules or slabs with a black manganese oxide coating (fig. $4 B$ ). Ions for cements and oxide coatings are supplied from the underlying suboxic sediments that contain up to $10 \%$ OC and have high measured benthic flux rates of phosphate, iron, manganese, and other ions out of the sediment. We also observed slabs that had been broken into fragments and turned over by strong bottom currents and (or) organisms (fig. 4C; fig. 12, Stage 4). Such fragments must be cemented together to form observed phosphorite "conglomerate" layers and pavements. We commonly observed nodules and broken fragments of phosphorite crust that were cemented onto the upper and lower surfaces of a pavement. The development of the dense, "mature" crusts must require multiple episodes of shallow burial and exhumation (Glenn and Arthur, 1988; Garrison and Kastner, 1990). These mature crusts usually show many generations of breaking and recementation (fig. 12, Stage 4) to form phosphorite pavements up to $10 \mathrm{~cm}$ thick composed of nodules and fragments and extending continuously for at least several tens of square kilometers as observed during our submersible dives. Phosphorite pavements commonly overlie somewhat indurated sediment, and in areas of slack currents, are covered by a blanket several centimeters thick of flocculent sediment. The pavement usually cannot be penetrated with a gravity corer or box corer. On the $12^{\circ} \mathrm{S}$ transect, we recovered samples from continuous phosphorite crusts growing on bedrock of unknown age exposed on the top and face of a cliff (probably a fault scarp) at water depths between 600 and $800 \mathrm{~m}$ and associated with diffuse "cold seep" venting (crab and clam congregations around bubbling methane). We suspect that the phosphorite pavement is frequently swept clean by strong bottom currents. Shifts in the strength and location of bottom currents and the OMZ contribute to the jumbled pattern of sedimentary assemblages and accumulation rates that are typical of the Peru margin (Reimers and Suess, 1983).

Below the most intense part of the OMZ (below about $450 \mathrm{~m}$ ), the upper surfaces of phosphorite pavements usually are covered with a dense population of epibionts whose hardparts often become cemented into the pavement. On a dive on the $13.5^{\circ} \mathrm{S}$ transect, at a water depth of $595 \mathrm{~m}$, we recovered a 3-cm-thick slab of dolomite-cemented sediment overlying glaucony with phosphorite nodules and fragments cemented on top of it. Original burrows and pore spaces between cemented phosphorite fragments are filled with sediment and cemented, helping to strengthen the pavement. Boring organisms continually riddle the surface of the pavement with holes, but these holes also are eventually filled with sediment and cement. Although we did not recover any phosphorite pavements or crusts buried by more than a few tens of centimeters of sediment, mature crusts (D-type phosphorite) have been recovered in ODP cores separated by up to several tens of meters of sediment (fig. 1; Garrison and Kastner, 1990). We suggest that the phosphorite crusts and pavements on the Peru margin can only become buried and incorporated into the geologic record once bottom currents slacken sufficiently to allow sediment to accumulate (fig. 12, Stage 5).

\section{Glaucony}

The widespread deposits of glaucony sand at depths below about $750 \mathrm{~m}$ on the slope at $13.5^{\circ} \mathrm{S}$ also indicate a bottom-current influence. The concentration of sand-sized glaucony pellets in the upper 10 to $35 \mathrm{~cm}$ of box cores recovered from these depths indicates that fine-grained 
material must have been winnowed from the deposit because it seems unlikely that relatively pure glaucony can precipitate in place without accumulation of fine-grained sediment. The glaucony sands directly overlie more clay-rich glaucony-bearing sediments in a number of the box cores recovered from 750 to $1,067 \mathrm{~m}$ on this transect, and as discussed above, the glaucony mica is presumed to have formed within those underlying clay-rich strata. Observations and measurements made during submersible dives, however, would suggest that strong currents are not currently active at these depths because the sediment surface is characterized by abundant tracks, trails, and mounds produced by burrowing organisms. Polychaete worms were also very abundant on the sediment surface. It is possible either that the activity of organisms is sufficient to rework and suspend fine-grained sediment that can then be transported by weaker bottom currents, or that currents in the recent past were stronger at this depth and concentrated the glaucony pellets as a lag deposit and are now sufficiently fast enough to prevent deposition of fine-grained particles.

\section{Summary of Controls on Geochemical Facies Patterns}

On the two transects studied, the outer shelf and upper slope are characterized by (1) mud or calcareous-phosphatic sand partly stabilized by bacterial mats; (2) benthic-foraminifera-rich, thick, organic flocs overlying indurated muds or crusts; (3) extensive authigenic (phosphorite and dolomite) mineral crusts and phosphatic biogenic debris; and (4) glaucony pellet sands. These four facies types are arrayed roughly in successive broad bands with increasing depth on the margin (fig. 5). The primary controls on facies distribution on the Peru margin are redox conditions and sediment transport and reworking by strong bottom currents. The concentration and preservation of organic matter on the Peru margin are strongly related to location and intensity of bottom currents as has previously been suggested by Suess and others (1987) and further documented by Arthur and others (1998).

Gaps in sampling for geochemical analyses that can be noted in the OC depth profiles (figs. 6, 7, and 8) result from hard bottoms (mostly phosphorite crusts and nodule horizons) that could not be penetrated by push cores or box cores. Such a gap occurs in the 200- to 300-m depth interval on the $13.5^{\circ} \mathrm{S}$ transect where the currents are strongest (fig. $3 B$ ) and CFA cementation is greatest (fig. 8C). Sediments in the current-swept regions commonly are enriched in silt- and sand-sized phosphatic grains and benthic foraminifera. From the submersible, observers commonly noted high particulate concentrations in the near-bottom region, as well as traction transport of organic flocs and benthic foraminifera at the sediment-water interface at depths characterized by strong currents. The high concentrations of $\mathrm{CaCO}_{3}$ from $100 \mathrm{~m}$ to about $400 \mathrm{~m}$ on both transects (fig. 6) result from high benthic foraminifera production in OC-rich sediments accompanied by winnowing of fines and concentration of foraminifera tests.

Therefore, constant advection of DO in low concentrations by bottom waters, resuspension of surficial organic matter, activity of organisms, and transport to and from more oxygenated zones contributes to greater oxidation of organic matter than might be expected under a strong OMZ (Arthur and others, 1998). The winnowing and transport of finer grained material results in lag deposits consisting of benthic foraminifera, terrigenous grains, and phosphatic sand over much of the upper slope that contain poorly preserved organic matter as indicated by low pyrolysis hydrogen indices (figs. $6 B$ and $E$; Arthur and others, 1998). This process also concentrates fine-grained, OC-rich sediments in certain sheltered regions of the upper slope and transports that material to deeper regions of the slope (Pak and others, 1980; Suess and others, 1987). Similar processes reportedly characterize the Oman margin where low 
values of $\mathrm{HI}(220-320)$ and high $\mathrm{C} / \mathrm{N}$ ratios in organic matter were attributed by Pedersen and others (1992) to winnowing ("hydrodynamic factors") and attendant reworking of sediment that lead to progressive degradation of organic matter (see also Cowie and others, 1999). On the northwestern Mexican margin off Mazatlan, Ganeshram and others (1999) also found that values of HI were higher in sediments on the slope $(>300 \mathrm{~m})$ than on the shelf $(<300 \mathrm{~m})$ where current winnowing resulted in greater degradation of organic matter.

Redox patterns are controlled by the initial flux of labile organic matter, which in turn is influenced by a complex function of surface productivity, water depth, current velocity, and water-column DO. The glaucony facies on the $13.5^{\circ} \mathrm{S}$ transect, for example, occurs below the lower boundary of the OMZ where marginally oxic conditions and low settling fluxes of OC create the proper conditions for glaucony genesis and concentration by progressive winnowing of fine-grained material. Formation of abundant CFA, on the other hand, requires a relatively continuous source of dissolved phosphate, probably preferentially released during degradation of organic matter supplied at high rates to the sediment-water interface by settling and concentration by traction currents. The same currents must periodically strengthen to sweep the bottom clean of fine-grained material in order to produce concentrations of phosphorite pellets (Baturin, 1982; Burnett and others, 1988; Glenn and Arthur, 1988) and expose phosphorite crusts, which form over longer periods of time.

\section{Conclusions}

The sedimentary geochemical facies patterns on the Peru outer shelf and upper slope are primarily controlled by patterns of redox conditions and strength of bottom currents, both of which change through time. Redox has long been stressed as a control on sediment compositions in the Peru OMZ, but the importance of deep currents has not generally been recognized.

Redox patterns are a function of availability of labile organic matter, which is primarily related to the interplay between biologic productivity, water depth, and current winnowing. Outer shelf environments near the top of the OMZ (depth $<100 \mathrm{~m}$ ) are characterized by relatively high sedimentation rates of fine-grained material, moderate OC contents, and low oxygen conditions within the sediments. Not surprisingly, these conditions give rise to relatively high rates of sulfate reduction just below the sediment-water interface, supporting a sulfide-oxidizing biota (for example, filamentous Thioploca bacterial mats) at the interface and leading to formation of pyrite within the sediments. Relatively minor amounts of phosphorite and glaucony form in these environments, and the sediments are somewhat enriched in biogenic opal from diatom debris. The presence of Thioploca helps to stabilize the sediments under moderate current velocities.

Precipitation of CFA primarily occurs where concentrations of labile organic matter are highest - within the core of the OMZ. As argued in previous studies, phosphate for CFA formation is supplied by preferential release of organic $\mathrm{P}$ during organic matter decomposition, by dissolution of fish debris, by the operation of an iron-redox phosphate pump, and perhaps in association with activity of sulfide-oxidizing bacteria. Thus, most CFA is probably formed near the sediment-water interface. The band of phosphate-rich sediments predominantly at depths of $150-350 \mathrm{~m}$ extends at least from $12^{\circ} \mathrm{S}$ to $13.5^{\circ} \mathrm{S}$, covering at least 1,500 square kilometers.

Below the base of the OMZ (depth $>700 \mathrm{~m}$ ), at least on the $13.5^{\circ} \mathrm{S}$ transect, the flux of labile $\mathrm{OC}$ is greatly diminished and conditions are sufficiently oxidizing at and near the sediment-water interface to support a benthic macrofauna. These organisms stir and mildly oxygenate the sediment, preventing major sulfate reduction in shallow pore waters. Glaucony 
pellets form in this environment, which is characterized by marginally oxic conditions at the sediment-water interface and enhanced silica availability from dissolution of biogenic opal. Glaucony sands were recovered only on the $13.5^{\circ} \mathrm{S}$ transect below a depth of $700 \mathrm{~m}$, but their broader extent is suggested by Logvinenko and Romankevich (1973).

Although redox conditions determine the assemblage of authigenic minerals that precipitate and their geochemical properties, bottom currents are a major determinant of the relative concentration of authigenic phases in sediments on the Peru margin at present. The relatively high-velocity currents are most important as agents of winnowing and transport of fine-grained material such as clays and organic matter. Thus, the widespread phosphatic sand and phosphorite crusts at mid-depth in the OMZ and the glaucony sands below the lower boundary of the OMZ originate because of winnowing of clay and organic matter and resulting concentration of these relatively dense authigenic phases.

The predominantly authigenic origin of the sediments on the Peru margin and the importance of currents on slope sedimentation have important implications for sediment accumulation on other continental margins with strong OMZs and high organic productivity, such as Baja Balifornia (Mexico), Morocco, Oman, and southwest Africa.

\section{Acknowledgments}

We gratefully acknowledge the captain and crew of the $R / V$ Seward Johnson and the pilots and crew of the DS/V Johnson Sealink II for their outstanding support during the 1992 Peru expedition (SJ 1092). We thank R.A. Jahnke and C.R. Glenn for discussion and collaboration on aspects of Peru margin geochemistry. We also thank K.-C. Emeis, A.E.S. Kemp, J.R. Herring, D.Z. Piper, J. Dickens, G. Filippelli, M. Underwood, and J.A. Addison for helpful reviews of various drafts of the manuscript. This research was supported by the National Science Foundation (NSF OCE 9014801 to Arthur) and by the U.S. Geological Survey Global Change and Climate History Program (Dean).

\section{References}

Arthur, M.A., Dean, W.E., Neff, E.D., Hay, B.T., King, John, and Jones, Glenn, 1994, Varve calibrated records of carbonate and organic carbon accumulation over the last 2000 years in the Black Sea: Global Biogeochemical Cycles, v. 8, p. 195-217.

Arthur, M.A., Dean, W.E., and Laarkamp, Kirsten, 1998, Organic carbon accumulation and preservation in surface sediments on the Peru margin: Chemical Geology, v. 152, p. 273-286.

Baker, K.B. and Burnett, W.C., 1988, Distribution, texture and composition of modern phosphorite pellets in Peru shelf muds: Marine Geology, v. 80, p. 195-214.

Baturin, G.N., 1982, Phosphorites on the sea floor-Origin, composition, and distribution: New York, Elsevier Scientific, 343 p.

Briggs, P.H., 2002, The determination of forty elements in geological and botanical samples by inductively coupled plasma-atomic emission spectrometry, in Taggart, J.E., ed., Analytical methods for chemical analyses of geologic and other materials: U.S. Geological Survey OpenFile Report 02-223, p. G1-20.

Brockmann, C., Fahrbach, E., Huyer, A., and Smith, R.L., 1980, The poleward undercurrent along the Peru coast -5 to $15^{\circ} \mathrm{S}$ : Deep Sea Research Part A-Oceanographic Research Papers, v. 27 , p. $847-856$. 
Brown, D.P., 2011, Winter circulation anomalies in the western United States associated with antecedent and decadal ENSO variability: Earth Interactions, v. 15, p. 1-12.

Burnett, W.C., 1977, Geochemistry and origin of phosphorite deposits from off Peru and Chile: Geological Society of America Bulletin, v. 88, p. 813-823.

Burnett, W.C., 1980, Apatite-glauconite associations off Peru and Chile-Paleo-oceanographic implications: Journal of the Geological Society of London, v. 137, p. 764-767.

Burnett, W.C., and Veeh, H.H., 1977, Uranium series disequilibrium studies in phosphorite nodules from the west coast of South America: Geochimica et Cosmochimica Acta, v. 41, p. 755-764.

Burnett, W.C., Veeh, H.H., and Soutar, A., 1980, U-series, oceanographic and sedimentary evidence in support of recent formation of phosphate nodules off Peru, in Bentor, Y.K., ed., Marine phosphorites - Geochemistry, occurrence, genesis: Society of Economic Paleontologists and Mineralogists, Special Publication 29, p. 61-71.

Burnett, W.C., Beers, M.J., and Roe, K.K., 1982, Growth rates of phosphate nodules from the continental margin off Peru: Science, v. 215, p. 1616-1618.

Burnett, W.C., Roe, K.K., and Piper, D.Z., 1983, Upwelling and phosphorite formation in the ocean, in Suess, Erwin and Thiede, Jörn, eds., Coastal upwelling-Its sediment record. Part A, Responses of the sedimentary regime to present coastal upwelling: New York, Plenum, p. 377-397.

Burnett, W.C., Baker, K.B., Chin, P.A., McCabe, William, and Ditchburn, Robert, 1988, Uranium-series and AMS ${ }^{14} \mathrm{C}$ studies of modern phosphatic pellets from Peru shelf muds, in Burnett, W.C., and Froelich, P.N., eds., The origin of marine phosphorite-Results of the $R$. $V$. Robert D. Conrad Cruise 23-06 to the Peru shelf: Marine Geology, v. 80, p. 215-230.

Burnett, W.C., Glenn, C.R., Yeh, C.C., Schultz, M., Chanton, J., and Kashgarian, M., 2000, Useries, ${ }^{14} \mathrm{C}$, and stable isotope studies of recent phosphatic "protocrusts" from the Peru margin, in Glenn, C.R., Prévôt, Liliane, and Lucas, Jacques, eds., Marine authigenesis -From global to microbial: Society of Economic Paleontologists and Mineralogists, Special Publication 66, p. 163-183.

Byrne, R.H., Liu, Xuewu, and Schijf, Johan, 1996, The influence of phosphate coprecipitation on rare earth distributions in natural waters: Geochimica et Cosmochimica Acta, v. 60, p. 33413346.

Calvert, S.E., Bustin, R.M., and Pedersen, T.F., 1992, Lack of enhanced preservation of sedimentary organic-matter in the oxygen minimum of the Gulf of California: Geology, v. 20, p. 757-760.

Collier, R.W., and Edmond, John, 1984, The trace element geochemistry of marine biogenic particulate matter: Progress in Oceanography, v. 13, p. 113-199.

Cowie, G.L., Calvert, S.E., Pedersen, T.F., Schulz, Hartmut, and von Rad, Ulrich, 1999, Organic content and preservational controls in surficial shelf and slope sediments from the Arabian Sea (Pakistan Margin): Marine Geology, v. 161, p. 23-38.

Crusius, John, Calvert, Stephen, Pedersen, Thomas, and Sage, David, 1996, Rhenium and molybdenum enrichments in sediments as indicators of oxic, suboxic and sulfidic conditions of deposition: Earth and Planetary Science Letters, v. 145, p. 65-78.

Dean, W.E., and Gardner, J.V., 1998, Pleistocene to Holocene contrasts in organic matter production and preservation on the California continental margin: Geological Society of America Bulletin, v. 110, p. 888-899. 
Dettinger, M.D., Cayan, D.R., Diaz, H.F., and Meko, D.M., 1998, North-south precipitation patterns in western North America on interannual to decadal timescales: Journal of Climate, v. 11, p. 3095-3111.

DeVries, T.J., and Pearcy, W.G., 1982, Fish debris in sediments of the upwelling zone off central Peru-A late Quaternary record: Deep Sea Research Part A-Oceanographic Research Papers, v. 29, p. 87-95, 97-109.

Engleman, E.E., Jackson, L.L., Norton, D.R., and Fischer, A.G., 1985, Determinations of carbonate carbon in geological materials by coulometric titration: Chemical Geology, v. 53, p. $125-128$.

Froelich, P.N., Klinkhammer, G.P., Bender, M.L., Luedtke, N.A., Heath, G.R., Cullen, Doug, Dauphin, Paul, Hammond, Doug, Hartman, Blayne, and Maynard, Val, 1979, Early oxidation of organic matter in pelagic sediments of the eastern equatorial Atlantic-Suboxic diagenesis: Geochimica et Cosmochimica Acta, v. 43, p. 1075-1090.

Froelich, P.N., Bender, M.L., Luedtke, N.A., Heath, G.R., and DeVries, T., 1982, The marine phosphorus cycle: American Journal of Science, v. 282, p. 474-511.

Froelich, P.N., Arthur, M.A., Burnett, W.C., Deakin, M., Hensley, V., Jahnke, R., Kaul, L., Kim, K.-H., Roe, K., Soutar, A., and Vathakanon, C., 1988, Early diagenesis of organic matter in Peru continental margin sediments-Phosphorite precipitation, in Burnett, W.C., and Froelich, P.N., eds., The origin of marine phosphorite-Results of the R. V. Robert D. Conrad Cruise 23-06 to the Peru shelf: Marine Geology, v. 80, p. 309-343.

Ganeshram, R.A., Calvert, S.E., Pedersen, T.F., and Cowie, G.L., 1999, Factors controlling the burial of organic carbon in laminated and bioturbated sedeiments off NW MexicoImplications for hydrocarbon preservation: Geochimica et Cosmochimica Acta, v. 63, p. 1723-1734.

Garrison, R.E., and Kastner, M.T., 1990, Phosphatic sediments and rocks recovered from the Peru margin during ODP Leg 112, in Suess, Erwin, von Huene, Roland, and others, eds., Peru continental margin, sites 679-688-Scientific results: Proceedings of the Ocean Drilling Program, v. 112, p. 111-134.

Glenn, C.R., and Arthur, M.A., 1988, Petrology and major element geochemistry of Peru margin phosphorites and associated diagenetic minerals-Authigenesis in modern organic-rich sediments, in Burnett, W.C., and Froelich, P.N., eds., The origin of marine phosphoriteResults of the R. V. Robert D. Conrad Cruise 23-06 to the Peru shelf: Marine Geology, v. 80, p. 231-267.

Helz, G.R., Miller, C.V., Charnock, J.M., Mosselmans, J.F.W., Pattrick, R.A.D., Garner, C.D., and Vaughan, D.J., 1996, Mechanism of molybdenum removal from the sea and its concentration in black shales-EXAFS evidence: Geochimica et Cosmochimica Acta, v. 60, p. 3631-3642.

Kim, K.H., and Burnett, W.C., 1986, Uranium-series growth history of a Quaternary phosphatic crust from the Peruvian continental margin: Chemical Geology-Isotope Geoscience section, v. 58, p. 227-244.

Kim, K.H., and Burnett, W.C., 1988, Accumulation and biological mixing of Peru margin sediments, in Burnett, W.C., and Froelich, P.N., eds., The origin of marine phosphoriteResults of the R. V. Robert D. Conrad cruise 23-06 to the Peru shelf: Marine Geology, v. 80, p. 181-194. 
Klovan, J.E., and Miesch, A.T., 1976, Extended CABFAC and QMODEL computer programs for Q-mode factor analysis of compositional data: Computers and Geosciences, v. 1, p. 161178.

Kulm, L.D., Thornburg, T.M., Suess, Erwin, Resig, Johanna, and Fryer, Patricia, 1988, Clastic, diagenetic, and metamorphic lithologies of a subsiding continental block-Central Peru forearc, in Suess, Erwin, von Huene, Roland, and others, eds., Peru continental margin, sites 679-688-Initial reports: Proceedings of the Ocean Drilling Program, v. 112, p. 91-107.

Liebezeit, Gerd, and Wiesner, M.G., 1990, Pyrolysis of recent marine sediments-I.

Biopolymers, in Burand, B., and Béhar, F., eds., Advances in organic geochemistry 1989Part II. Molecular geochemistry: Organic Geochemistry, v. 16, 1179-1185.

Logvinenko, N.V., and Romankevich, Y.A., 1973, Recent sediments of the Pacific Ocean off the coasts of Peru and Chile: Litologiya i Poleznyye Iskopayemyyo, v. 1, p. 123-136.

Nishimura, T., 1994, Occurrence and properties of glauconite in Miocene biosiliceous sediments of the Noto Peninsula, Hokuriku District, Japan, in Iijima, Azuma, Abed, A.M., and Garrison, R.E., eds., Proceedings of the 29th International Geological Congress - Part C. Siliceous, phosphatic, and glauconitic sediments of the Tertiary and Mesozoic: Utrecht, VSP, p. 75-87.

Odin, G.S., 1985, La "verdine," faciès granulaire vert, marin et côtier, distinct de la glauconieDistribution actuelle et composition: Comptes Rendus de l'Académie des Sciences-Série 2, 301, p. 105-113.

Odin, G.S., ed., 1988, Green marine clays: Elsevier, Developments in Sedimentology 45, 445 p.

Odin, G.S., and Letolle, R., 1980, Glauconitization and phosphatization environments-A tentitive comparison, in Bentor, Y.K., ed., Marine phosphorites- Geochemistry, occurrence, genesis: Society of Economic Paleontologists and Mineralogists, Special Publication 29, p. 227-237.

Pak, Hasong, Codispoti, L.A., and Zaneveld, J.R.V., 1980, On the intermediate particle maxima associated with oxygen-poor water off western South America: Deep Sea Research Part AOceanographic Research Papers, v. 27, p. 783-798.

Pedersen, T.F., Shimmield, G.B., and Price, N.B., 1992, Lack of enhanced preservation of organic-matter in sediments under the oxygen minimum on the Oman Margin: Geochimica et Cosmochimica Acta, v. 56, p. 545-551.

Peters, K.E., 1986, Guidelines for evaluating petroleum source rock using programmed pyrolysis: American Association of Petroleum Geologists Bulletin, v. 70, p. 318-329.

Piper, D.Z., 1994, Seawater as the source of minor elements in black shales, phosphorites, and other sedimentary rocks: Chemical Geology, v. 114, p. 95-114.

Piper, D.Z., and Dean, W.E., 2002, Trace-element deposition in the Cariaco Basin, Venezuela Shelf, under sulfate-reducing conditions - A history of the local hydrography and global climate, 20 ka to the present: U.S. Geological Survey Professional Paper 1670, 41 p.

Pratt, L.M., 1984, Influences of paleoenvironmental factors on preservation of organic matter in middle Cretaceous Greenhorn Formation: American Association of Petroleum Geologists Bulletin, v. 68, p. 1146-1159.

Reimers, C.E., and Suess, Erwin, 1983, Spatial and temporal patterns of organic matter accumulation of the Peru continental margin, in Thiede, Jörn, and Suess, Erwin, eds., Coastal upwelling - Its sediment record. Part B, Sedimentary records of ancient coastal upwelling: New York, Plenum, p. 311-345.

Schuffert, J.D., Kastner, Miriam, and Jahnke, R.A., 1998, Carbon and phosphorus burial associated with modern phosphorite formation: Marine Geology, v. 146, p. 21-31. 
Smith, P.E., Evensen, N.M., York, Derek, and Odin, G.S., 1998, Single-grain ${ }^{40}$ Ar- ${ }^{39}$ Ar ages of glauconies-Implications for the geologic time scale and global sea level variations: Science, v. 279, p. 1517-1519.

Suess, Erwin, 1981, Phosphate regeneration from sediments of the Peru continental margin by dissolution of fish debris: Geochimica et Cosmochimica Acta, v. 45, p. 577-588.

Suess, E., Kulm, L.D., and Killingly, J.S., 1987, Coastal upwelling and a history of organic-rich mudstone deposition off Peru, in Brooks, J., and Fleet, A.J., eds., Marine petroleum source rocks: Geological Society (London), Special Publication 26, p. 181-197.

Suits, N.S., and Arthur, M.A, 2000, Sulfur diagenesis and partitioning in Holocene Peru shelf and upper slope sediments: Chemical Geology, v. 163, p. 219-234.

Taggart, J.E., Jr., Lindsay, J.R., Scott, B.A., Vivet, D.V., Bartel, A.J., and Stewart, K.C., 1987, Analysis of geologic materials by wavelength-dispersive X-ray fluorescence spectrometry, in Baedecker, P.A., ed., Methods for geochemical analysis: U.S. Geological Survey Bulletin 1770, p. E1-E19.

Tissot, B.P., and Welte, D.H., 1984, Petroleum formation and occurrence (2d ed.): Berlin, Springer-Verlag, $538 \mathrm{p}$.

Wedepohl, K.H., 1995, The composition of the continental crust: Geochimica et Cosmochimica Acta, v. 59, p. 1217-1232. 